\title{
Dos efectos de la COVID-19 en Colombia: profundización de la desigualdad y retorno al hiperpresidencialismo
}

Two effects of COVID-19 in Colombia: deepening inequality and a return to hyperpresidentialism

Autor: Pedro Javier Barrera Varela

DOl: https://doi.org/10.19053/16923936.v18.n36.2020.12158

Para citar este artículo:

Barrera Varela, P. J. (2020). Dos efectos de la COVID-19 en Colombia: profundización de la desigualdad y retorno al hiperpresidencialismo. Revista Derecho y

Realidad, 18, (36), 59-88. 


\title{
DOS EFECTOS DE LA COVID-19 EN COLOMBIA: PROFUNDIZACIÓN DE LA DESIGUALDAD Y RETORNO AL HIPERPRESIDENCIALISMO*
}

Two effects of COVID-19 in Colombia: deepening inequality and a return to hyperpresidentialism

Dois efeitos do COVID-19 na Colômbia: aumento da desigualdade e um retorno ao hiperpresidencialismo

\author{
Pedro Javier Barrera Varela ${ }^{\mathbf{a}}$ \\ pjabogado26@gmail.com
}

Recepción: 12 de octubre 2020

Aceptación: 02 de noviembre 2020

\section{RESUMEN}

El presente artículo tiene como objeto analizar desde una postura crítica, con soporte teórico y fáctico, los cambios que ha sufrido el ordenamiento jurídico colombiano a partir de la declaratoria del Estado de excepción. La investigación propone como tesis que el excesivo incremento normativo en cabeza del legislador excepcional arrojó dos nefastas consecuencias para la sociedad colombiana: profundización de la desigualdad y retorno al hiperpresidencialismo. Así, para sustentar la tesis anteriormente mencionada, se desarrollaron tres argumentos. Primero, se plantea que en el contexto colombiano persisten dos constantes: desigualdad y exclusión. Para defender esta premisa fueron analizadas algunas sentencias proferidas por las altas cortes y datos estadísticos que la confirman. También, se presenta la radiografía del derecho a la salud, la cual pone en evidencia que el sector padece la enfermedad de la corrupción sistémica. Segundo, se analiza el diseño constitucional colombiano para concluir que, en el escenario actual, los distintos poderes han sido cooptados por el presidente de la

\footnotetext{
* Artículo de reflexión. Agradezco la ayuda de mi amigo y estudiante de derecho, Luis Miguel Farfán Miranda, para la búsqueda y sistematización de las sentencias proferidas por la Corte Constitucional en ejercicio de control automático de constitucionalidad. Asimismo, agradezco los aportes del colega y economista Jhon Cote que me permitieron aclarar dudas frente al Decreto Legislativo 444 "Creación del FOME".

a. Candidato a doctor en derecho por la Universidad Externado de Colombia. Magíster en derecho administrativo y especialista en derecho constitucional. Profesional Especializado grado 33 de la Sección Primera del Consejo de Estado de Colombia. Docente de posgrados en áreas del derecho público.
} 
república. Tercero, se realiza una valoración crítica de los decretos legislativos expedidos en el marco del Estado de excepción, y se concluye que, por lo menos, 34 decretos eran innecesarios, inconvenientes o inconstitucionales. Lo más crítico del último argumento fue evidenciar el débil papel de la Corte Constitucional en su ejercicio de control automático de constitucionalidad.

\section{PALABRAS CLAVES}

Desigualdad; exclusión; diseño constitucional colombiano; cooptación del poder; decretos legislativos; hiperproducción normativa y control automático de constitucionalidad.

\section{ABSTRACT}

The purpose of this article is to analyze, from a critical position, with theoretical and factual support, the changes that the Colombian legal system has undergone since the declaration of the State of Emergency. The research proposes, as a thesis, that the excessive normative increase at the head of the exceptional legislator produced two dire consequences for Colombian society: a deepening of inequality and a return to hyper-presidentialism. Thus, to support the above-mentioned thesis, three arguments were developed. First, we propose that in the Colombian context two constants persist: inequality and exclusion. To defend this premise, we analyzed some sentences issued by the high courts and statistical data that confirms them. We also presented an X-ray of the right to health, which shows that this sector suffers from the disease of systemic corruption. Second, we analyzed the Colombian constitutional design and concluded that, in the current scenario, the different powers have been co-opted by the president of the republic. Third, we conducted a critical assessment of the legislative decrees issued under the state of emergency, and concluded that at least 34 decrees were unnecessary, inconvenient, or unconstitutional. The most critical aspect of the last argument was to highlight the weak role of the Constitutional Court in its exercise of automatic control of constitutionality.

\section{KEYWORDS}

Inequality; exclusion; Colombian constitutional design; co-optation of power; legislative decrees; normative hyperproduction and automatic control of constitutionality.

\section{RESUMO}

0 objetivo deste artigo é analisar a partir de uma postura crítica, com suporte teórico e factual, as mudanças por que passou o ordenamento jurídico colombiano desde a declaração do Estado de Exceção. A investigação propõe como tese que o excessivo aumento regulatório à frente do excepcional legislador teve duas consequências terríveis para a sociedade colombiana: aprofundamento da desigualdade e retorno ao hiperpresidencialismo. Assim, para embasar a referida tese, três argumentos foram desenvolvidos. Em primeiro lugar, propomos que duas constantes persistem no contexto colombiano: desigualdade e exclusão. Para defender esta premissa, foram analisadas algumas sentenças proferidas pelos tribunais superiores e dados estatísticos que a confirmam. Também é apresentada a radiografia do direito à saúde, que mostra que o setor sofre com a doença da corrupção sistêmica. Em segundo lugar, analisase o desenho constitucional colombiano para concluir que, no cenário atual, os diferentes poderes foram cooptados pelo presidente da república. Terceiro, é feita uma avaliação crítica dos decretos legislativos emitidos no âmbito do estado de exceção, e conclui-se que pelo menos 34 decretos foram desnecessários, inconvenientes ou inconstitucionais. 0 mais crítico do último argumento foi mostrar a fragilidade do papel do Tribunal Constitucional no exercício do controle automático da constitucionalidade.

\section{PALAVRAS-CHAVE:}

Desigualdade; exclusão; desenho constitucional colombiano; cooptação de poder; decretos legislativos; hiperprodução normativa; controle automático da constitucionalidade. 


\section{SUMARIO}

Introducción.

1. El contexto colombiano en tiempos de COVID-19.

2. Equilibrio de poderes en la Constitución Política de Colombia: La pandemia en tiempos de desbalance institucional.

3. Estado de excepción en Colombia: hiperproducción normativa del Ejecutivo vs débil control constitucional.

Conclusiones.

Referencias bibliográficas.

\section{INTRODUCCIÓN}

Parece que a Iván Duque no le basta ser presidente, que es un cargo poderoso, ni tampoco ser un duque, que es un prestigioso título de nobleza; parece que quisiera ser una especie de monarca absoluto, como Luis $X I V$, que pudiera decir "el Estado soy yo", por cuanto está copando las funciones y los poderes del Estado. Con una diferencia no menor: que Luis XIV supo siempre rodearse de excelentes ministros: algo va de su legendario ministro de finanzas Colbert a... Carrasquilla. Rodrigo Uprimny

1. En el Estado social de derecho colombiano no existe posibilidad de que el presidente de la república se reelija. En teoría, sería una manera efectiva de evitar excesos en un gobierno presidencialista que, mediante un sistema de reelección, podría generar una fractura en el diseño institucional $y$ recaer en una forma hiperpresidencialista. Sin embargo, se cree que el exceso de concentración de poder en cabeza del gobierno del presidente Duque, y su habilitación constitucional para expedir decretos con fuerza material de ley para conjurar la pandemia, justifican la tesis del retorno al hiperpresidencialismo. La presente investigación responde a la pregunta: ¿cuáles fueron los excesos del Gobierno Nacional en su función de legislador excepcional durante los dos estados de excepción declarados en Colombia?
2. Esa excesiva concentración del poder por parte del presidente de la república genera otro efecto perverso: la profundización de la desigualdad. El artículo intenta demostrar que un gran número de decretos legislativos no eran necesarios para conjurar la situación de crisis causada por la COVID-19. Por el contrario, en varios de estos decretos se puede observar cómo las decisiones del Gobierno Nacional buscan privilegiar sectores específicos o grandes capitales sin que tengan un alcance real sobre la población más vulnerable. Por lo anterior, con apoyo en la teoría crítica, que permite valorar la realidad social colombiana, se analizara la grave crisis constitucional que vive el país. Existe pleno convencimiento de que el nuevo coronavirus, en Colombia, sirvió de excusa para degenerar en una forma de gobierno hiperpresidencialista.

3. Para lograr dicho propósito, es necesario exponer, en primer término, la crisis de desigualdad que caracteriza al Estado colombiano y su impacto en el sistema de salud. En segundo término, es imperativo abordar la conformación y diseño institucional del poder público en Colombia. En tercer término, se analizarán los poderes legislativos del Gobierno Nacional en el marco del estado de excepción, y se sustentará la tesis según la cual se incurrieron en excesos por parte del legislador excepcional. Por último, se realizará una conclusión sobre el débil papel de la Corte Constitucional en su ejercicio de juez controlador de los poderes excepcionales del Ejecutivo.

\section{EL CONTEXTO COLOMBIANO EN TIEMPOS DE COVID-19}

\section{a. Dos constantes: desigualdad y exclusión}

4. Amartya Sen recuerda que la lucha contra la injusticia no es un tema que cobre gran relevancia. Sin embargo, recalca que existen injusticias tan extremas que no pueden pasarse por alto, y que frente a ellas se debe tomar algún tipo de acción (Sen, 2011). De igual manera, la pandemia de la COVID-19 genera en algunos países un tipo de inequidades e injusticias que serían tolerables. Pero en otras naciones 
que estaban acostumbradas a una extrema desigualdad e injusticia, la COVID-19 se convierte en un detonador que amplía la ya existente brecha social. Al hacer referencia a Colombia, se advierte que se trata de uno de los países cuya desigualdad es profunda. La desigualdad en el país se observa en los distintos ámbitos: ingreso, educación, salud, vivienda, movilidad, alimentación y servicios públicos domiciliarios.

5. El escenario desigual queda representado a partir de 4 casos recientes en los que los altos tribunales colombianos han tenido que amparar los derechos de: i) vivienda digna a una comunidad residente en un barrio del sur de Bogotá, ii) educación de unos niños que estudiaban en una escuela rural y no tenían accesibilidad al centro educativo, iii) acceso al servicio de la internet de una escuela del sector rural como garantía del derecho a la educación y iv) asistencia humanitaria a una comunidad indígena en el Estado de emergencia.

6. En el primer caso, la Corte Constitucional, mediante sentencia del 14 de enero de 2019, amparó el derecho a la vivienda digna de 14 familias. Se trata de habitantes del sector "Villa Cali II" de la localidad de Bosa, ubicada al sur de Bogotá, quienes habían construido unas viviendas sin contar con la respectiva licencia urbanística. Por lo anterior, la Alcaldía Local de Bosa, previa actuación administrativa, ordenó la demolición de las viviendas y solicitó a las empresas prestadoras que se les suspendieran los servicios públicos domiciliarios. El tribunal constitucional ordenó a esta alcaldía local la suspensión de estas órdenes. Además, solicitó a esta dependencia que se realizara un estudio técnico para verificar la estabilidad y habitabilidad de las 14 viviendas. Y, que, en caso, de ser necesaria la reubicación debería ofrecer un albergue temporal a las familias que estuviesen expuestas a un riesgo no tolerable. (Corte Constitucional, 2019).

7. Según el informe de déficit habitacional del Departamento Nacional de Estadística (en adelante DANE), presentado en abril de 2020, con base en el Censo Nacional de Población y Vivienda 2018, de un total de $14^{\prime} 060.645$ hogares colombianos ${ }^{1}$ distribuidos en 11'118.577 en cabeceras municipales y 2'942.068 en centros poblados y rurales dispersos, existe un déficit habitacional promedio del 36,6\%. El promedio total se obtiene de sumar el déficit cuantitativo $^{2}$ del $9.8 \%$ y el cualitativo ${ }^{3}$ de un $26.8 \%$. En las cabeceras municipales el déficit cuantitativo es del $6.1 \%$ y el cualitativo $18.7 \%$, mientras que en los centros poblados y rurales dispersos el déficit cuantitativo es del $23,7 \%$ y el cualitativo del 57,2\% (DANE, Déficit habitacional, 2020) Así, se llama la atención a los tres aspectos principales del fallo en cuestión y del contexto de déficit habitacional en nuestro país.

8. Primero, lo reciente de la sentencia, de enero de 2019. Su cercanía temporal implica que no se trata de hechos pasados, sino del presente de muchas familias colombianas que se encuentran en condiciones de insatisfacción de su derecho fundamental a la vivienda. Segundo, que no se trata de una población vulnerable, sino de colombianos que de alguna manera podrían tener acceso a vivienda propia. Tercero, resulta relevante que la situación de vulneración no se presente en uno de los municipios periféricos del país, sino en su ciudad capital. En consecuencia, queda demostrado el alto déficit de desprotección de un derecho fundamental que adquiere mayor peso en tiempos de pandemia, el derecho a la vivienda digna. En época de aislamiento obligatorio, el sitio de residencia se convierte, para millones de colombianos, no solo en el lugar de habitación, sino también de trabajo, educación y recreación. No cabe duda, la pandemia trata a las personas de manera desigual, dependiendo qué tan satisfecho se encuentre el derecho fundamental a la vivienda.

1. La cifra no incluye grupos étnicos.

2. Dentro del déficit cuantitativo se encuentran las siguientes condiciones: tipo de vivienda, materiales de las paredes exteriores, cohabitación y hacinamiento no mitigable.

3. Dentro del déficit cualitativo se encuentran las siguientes condiciones: hacinamiento mitigable, material de los pisos, cocina y servicios públicos. 
9. En el segundo caso, la Corte Constitucional amparó el derecho a la educación de los estudiantes de la escuela de la vereda San José de Campo de Lajas del municipio de Sardinata, Norte de Santander. Los niños y niñas que estudian en dicho centro educativo han tenido dificultades para acudir a su escuela, debido a que el puente "La hamaca" que habilita el cruce del río Nuevo Presidente se quebró. Los infantes que estudian allí arriesgan su vida a diario para poder gozar del derecho a la educación. En el río hay presencia de caimanes, lo que pone en alto riesgo la vida de estos infantes. La tutela fue declarada improcedente en primera instancia, pero, finalmente, la Corte tuteló el derecho fundamental a la educación "dado que los niños, niñas y adolescentes de la vereda de San José de Campo Lajas enfrentan barreras de acceso desproporcionadas para llegar a la Institución Educativa San Luis Beltrán" (Corte Constitucional T-209, 2019).

10. Sin embargo, no se comparte la orden que se desprendió del amparo al derecho fundamental. El alto tribunal, en lugar de emitir una orden directa a las autoridades accionadas, municipio de Sardinata y departamento de Norte de Santander, propuso un proceso de interacción significativa entre las autoridades accionadas y la comunidad. El objeto de la decisión fue buscar un consenso bajo el cual se diera solución a la vulneración de derechos. En la parte resolutiva no se determinaron plazos ciertos para realizar ese diálogo o interacción significativa, e incluso se dejó la labor del seguimiento al juez de instancia que había declarado improcedente la acción de tutela. Por el contrario, el autor considera que la Corte debió haber pronunciado una orden directa con unos plazos ciertos ${ }^{4}$ que permitieran solucionar el déficit de protección que tenía esta comunidad frente al derecho a la educación. La metodología de interacción significativa en las órdenes de una sentencia judicial puede ser de

4. En la sentencia se determinó un plazo de 3 meses para que las autoridades informaran de los avances de las obras y compromisos a los que se hubiesen llegado. Como se advierte, dicho plazo no debe interpretarse como un término perentorio para dar solución a la problemática. gran utilidad en casos de gran impacto. Por ejemplo, en los amparos estructurales. En estos procesos, el juez se encuentra en graves aprietos para construir órdenes precisas y directas en su fallo. Por esta razón, se reitera que, en el presente caso, donde la orden saltaba a la vista "reconstrucción del puente"- incluso la obra se cuantificó por el departamento accionado en 30 millones COP-, no resultaba necesario acudir a esta metodología y prolongar la situación de vulneración del derecho ${ }^{5}$.

11. En el tercer caso, el tribunal constitucional amparó el derecho a la educación y ordenó a la Gobernación de Antioquia que adoptara las medidas necesarias para mitigar el impacto de la falta de prestación del servicio de internet en una escuela rural ubicada en el municipio de Jericó, Antioquia (Corte Constitucional, T-030, 2020). El fallo refleja la realidad y desigualdad del sistema educativo en Colombia. En tiempos de pandemia las clases presenciales han sido reemplazadas por las sesiones virtuales. Este cambio implica tener acceso a unos mínimos: plan de internet, equipo de cómputo, y un lugar en casa que se pueda destinar para las jornadas de estudio. En esta medida, en Colombia, la conectividad, condición necesaria para la educación virtual, sólo sigue siendo privilegio de unos pocos. Ligarreto, apoyándose en el DANE, informa que en las zonas urbanas la conectividad alcanza un $89 \%$ mientras que en zonas rurales solo llega a un 26\% (2020). El DANE, en el informe sobre la población negra, afrocolombiana, raizal y palenquera, con base en el censo de 2018, estableció que la cobertura de internet en viviendas con jefatura de estas comunidades es de tan solo el $26,9 \%$, mientras el total nacional es del 43.3\%. (DANE, 2019a). En el informe sobre población indígena de Colombia se determinó que la cobertura de Internet en viviendas con hogares de jefatura indígena es de tan solo el 6.4\%. (DANE, Población indígena en Colombia, 2019).

5. La magistrada Diana Fajardo aclaró su voto en el sentido de no apoyar la metodología implementada en las órdenes del fallo de tutela. 
12. En el cuarto caso, el Consejo de Estado, mediante sentencia de 2 de julio de 2020, amparó los derechos fundamentales a la vida, alimentación e integridad física y cultural de los seis resguardos que integran la etnia indígena Yukpa. Este pueblo indígena tiene la particularidad de gozar de protección especial constitucional por su condición de nómada, seminómada y agricultor itinerante. La Corte Constitucional, en el auto 004 de 2009 , proferido en el marco del seguimiento a la sentencia T-025 de 2004, "advirtió su riesgo de exterminio físico y cultural". Con ocasión de la crisis sanitaria generada por la COVID-19, su situación de vulneración se vio agravada, pues se requieren ayudas para 1.790 familias que componen su comunidad. Además, por su condición de nómadas requieren desplazamiento constante, lo cual se ha visto limitado por los decretos de aislamiento preventivo obligatorio dictados por el Gobierno. Por esta razón, han tenido que estar confinados en pequeños resguardos en los que escasea el alimento y los insumos sanitarios esenciales. En primera instancia, el Tribunal Administrativo del Cesar negó el amparo solicitado. Por su parte, el Consejo de Estado revocó parcialmente la decisión y ordenó que en un término máximo de 5 días se hicieran las gestiones para el transporte y entrega de las ayudas humanitarias en los territorios donde se encuentran las familias indígenas de esta comunidad. Esta ayuda humanitaria deberá entregarse a los seis resguardos que componen el pueblo indígena Yukpa y deberá mantenerse mientras dure la emergencia sanitaria en el país. (Consejo de Estado, 2020)

13. Los grupos étnicos en Colombia se caracterizan por tener una mayor condición de vulnerabilidad que el resto de la población. Según el estudio del DANE ya mencionado, mientras el $76.6 \%$ de la totalidad de hogares colombianos tienen cobertura de alcantarillado en sus viviendas, la cobertura para la población indígena es del 23,0\%. El servicio de gas natural solo tiene cobertura del $15,3 \%$ en las viviendas indígenas frente al $66.8 \%$ del total nacional. En relación con la cobertura de recolección de basuras en viviendas con hogares de jefatura indígena solo se alcanza a un $25.5 \%$, en tanto que en el total nacional es del 81.6\% (DANE, Población indígena en Colombia, 2019). De acuerdo con estas cifras, resulta fehaciente la advertencia que hace Murillo frente al grave riesgo de extinción que padecen los grupos étnicos, pues son más de 40 pueblos indígenas los que cuentan con menos de 500 integrantes, y de estos 100 tienen población menor a 100 personas. La población indígena ronda la cifra de 2 millones, y se advierte que en su mayoría "no cuentan con acceso a agua potable en sus casas" (Murillo, 2020). Por lo tanto, si una de las medidas efectivas para combatir la COVID-19 es el constante lavado de manos, esta medida no es accesible para las comunidades indígenas que no cuentan con sistemas de alcantarillado en sus hogares.

14. A esto debe sumarse, tal y como lo plantea la facultad de economía de la Universidad de los Andes, que las unidades de cuidados intensivos, UCI, "se encuentran más alejadas para las comunidades indígenas y negras que para el resto del país". En promedio las UCI se ubican a $198,53 \mathrm{~km}$ para la población indígena y a $81.49 \mathrm{~km}$ para las comunidades negras. Además, se presenta un difícil acceso desde los territorios étnicos a los centros hospitalarios por la falta de carreteras y de medios que faciliten el transporte fluvial. El estudio pone de relieve el hecho de que cinco departamentos amazónicos, a julio del 2020, no tuviesen ni una sola UCI, estos son: Amazonas, Vaupés, Vichada, Guainía y Guaviare, a pesar de las altas tasas de contagio presentadas allí. En suma, la facultad de economía señala la necesidad de implementar políticas diferenciales bajo las cuales se puedan mitigar los graves efectos de la pandemia en los grupos étnicos (Bermúdez, 2020).

15. Los cuatro casos judiciales demuestran que la COVID-19, por una parte, afecta con mayor agresividad a los sectores más vulnerables de la sociedad, y, por la otra, aumenta la brecha de exclusión y desigualdad. Recientemente, la facultad de economía de la Universidad de los Andes publicó un estudio sobre los graves efectos de la pandemia en los segmentos socioeconómicos más vulnerables. El informe 
se centró en el caso de Bogotá y se soportó en los datos sobre contagios, hospitalizaciones y muertes por estrato social. Se concluyó, por ejemplo, que alguien del estrato 1 tiene 10 veces más probabilidades de ser hospitalizado o morir por el virus, si se le compara con una persona del estrato 6. A 27 de julio, las hospitalizaciones por COVID-19 en los estratos arrojaban los siguientes resultados: 1: 93.03, 2: 56.39, 3: 27.82, 4:11.57, 5:9.16, y 6:7.98. La investigación descarta las hipótesis de que los estratos más bajos tengan mayores problemas de salud o reciban menor atención médica que los estratos más altos. Por el contrario, la hipótesis que defienden que en los estratos más bajos existe mayor exposición al contagio, bien sea porque no pueden quedarse en casa pasando el aislamiento, o bien por su baja percepción sobre el riesgo de la enfermedad. (Andes, 2020). En suma, la COVID-19 en Colombia está dejando en evidencia la gran deuda que tiene el Estado en materia de mínimos de satisfacción de los derechos económicos, sociales, culturales y ambientales con sectores específicos de la población.

\section{b. Radiografía del derecho fundamental a la salud: corrupción sistémica}

16. Gañán recoge la crisis sistémica del derecho a la salud en su tesis doctoral: "Los muertos de la Ley 100" (Gañán, 2010). En Colombia, el derecho a la salud fue incluido por la constituyente dentro de los denominados derechos sociales, económicos y culturales. Tal inclusión, propició intensos debates en relación con la exigibilidad, vía tutela, de este derecho. El tribunal constitucional diseñó diferentes criterios, bajo los cuales se podría hacer efectivo el amparo del derecho a la salud. Uno de estos criterios es el de conexidad, que consiste en demostrar un nexo causal entre un derecho fundamental, vida, dignidad humana, integridad física, y el derecho a la salud. No obstante, el referido criterio terminó siendo reemplazado, pues, a juicio de la Corte, el derecho a la salud debe catalogarse como un derecho fundamental autónomo (Corte

6. La Ley 100 de 1993 creó el Sistema de Seguridad Social Integral en Colombia.
Constitucional, 2008). La sentencia fue producto de un amparo estructural ordenado por el alto tribunal, ante la necesidad de intervenir la política pública de salud, debido a las reiteradas y graves afectaciones a este derecho. Finalmente, el reconocimiento como "derecho fundamental autónomo e irrenunciable" fue plasmado en la Ley 1751 de 2015.

17. Se considera que el cambio de nombre del derecho a la salud en el ordenamiento jurídico no es suficiente. El sistema de salud colombiano continúa padeciendo una grave crisis. Dos razones sirven de apoyo para sustentar esta tesis. En primer lugar, de un total de 812.908 acciones presentadas en todo el territorio nacional, dentro del período comprendido de enero de 2019 a marzo de 2020, 240.821 fueron por el derecho de salud. Sólo el derecho de petición superó el número de acciones impetradas. Los casos más reiterativos siguen siendo los mismos cuando aún no entraba en vigencia la ley estatutaria que le reconoció el carácter de derecho fundamental. Barrera, citando a la relatoría de la Corte Constitucional, informó que las tutelas más recurrentes en el sector salud se presentan por: i) práctica oportuna de procedimiento médico, ii) entrega oportuna de medicamentos o insumos, iii) tratamiento integral, iv) asignación de citas médicas; v) transporte y viáticos para recibir atención en salud y vi) valoración y diagnóstico médico (Barrera, 2020).

18. En segundo lugar, el derecho a la salud no ha sido ajeno al flagelo de la corrupción. En los últimos años se han descubierto los grandes cárteles de la salud: el cartel de la hemofilia, el cartel del VIH y la crisis de la salud en San Andrés, por ejemplo. Frente al primero, la Contraloría General de la República dictó fallos fiscales contra algunas autoridades de los departamentos de Córdoba, Bolívar y Caquetá que ascienden a la suma de $85.000^{7}$ millones de pesos colombianos. Con ocasión del mencionado cartel se convirtió al departamento de Córdoba como el territorio con el mayor

7. La cifra indicada equivale a 22 millones de dólares aproximadamente. 
número de pacientes hemofílicos por tasa de habitantes en el mundo. En el desfalco a los recursos del sistema de salud participaron senadores de la región, mandatarios locales, gobernadores y secretarios departamentales, y empresas particulares prestadoras de los servicios de salud (CGR, 2018). Frente al segundo, también en el departamento de Córdoba, el procurador general de la nación denunció un cartel cuyo objeto era apropiarse de los dineros destinados para la atención de pacientes con VIH-SIDA. Se cobró por lo menos un monto de 500 millones de pesos colombianos por pacientes inexistentes (Defensoría, 2019). Frente al tercero, la Defensoría Regional de San Andrés estaba al tanto de las constantes quejas por falta de profesionales en salud, insumos básicos, infraestructura y no pago de salarios ni de seguridad social al personal de salud. Deficiencias en la contratación del operador de los servicios de salud han motivado que la Superintendencia Nacional de Salud adelante investigaciones en contra de los prestadores del servicio. De igual modo, se trasladaron hallazgos a la contraloría y procuraduría por presuntas fallas fiscales (Ibid.). Por último, debe advertirse que algunas de las más grandes empresas que prestan los servicios de salud, Coomeva, Medimás, entre otras, han sido intervenidas por la Superintendencia Nacional de Salud ante el gran número de denuncias, quejas y acciones de tutela presentadas en su contra.

19. Se debe llamar la atención sobre otro aspecto de la crisis. Las condiciones laborales del personal de salud. Los profesionales de la salud tienen que acudir a acciones constitucionales, en plena pandemia, para reivindicar sus derechos laborales. Una trabajadora que desempeñaba el cargo de auxiliar administrativo en el Hospital San Vicente de Arauca acudió a la acción de tutela para que se le cancelara su salario de los meses de octubre a diciembre de 2019 y marzo de 2020. Aunque el Consejo de Estado declaró la carencia actual de objeto porque en sede de impugnación del fallo de primera instancia le fueron cancelados los salarios a la tutelante, hubo solicitudes de proferir una decisión inter comunis para que se ampararan los derechos de todos los trabajadores a quienes el Hospital accionado les adeudaba salarios. La falta de pago es un hecho de conocimiento público, advirtió el fallo. Sin embargo, el alto tribunal no extendió los efectos porque no había certeza probatoria que permitiera individualizar a los trabajadores que se encontraran en la misma situación. En la decisión se resolvió mantener el amparo a los derechos fundamentales al mínimo vital, vida digna y trabajo de la accionante. También, por un lado, instó al Hospital para que en caso de adeudar salarios u honorarios a sus servidores y contratistas realizara todas las gestiones necesarias para el pago. Y, por el otro, instó al Ministerio de Salud y Protección Social para que se realicen todos los trámites que permitan el pago efectivo de las entidades promotoras de salud al Hospital San Vicente de Arauca (Consejo de Estado, 2020).

20. Esta acción de tutela no se trata de un caso aislado, sino de una constante del talento humano que trabaja en el sector salud. La Superintendencia Nacional de Salud, durante los días 26 y 27 de mayo de 2020, realizó 28 visitas a diferentes Instituciones Prestadoras de Salud, IPS, para verificar tres aspectos: i) pago de salarios y honorarios, ii) entrega de elementos de protección personal y iii) disponibilidad de equipos biomédicos. La Superintendencia encontró que en 15 instituciones visitadas se incumple con por lo menos alguno de los tres criterios materia de revisión. Producto de esta labor de verificación y control se remitieron 68 denuncias al Ministerio del Trabajo por no pago de salarios (Supersalud, 2020). Existen continuas quejas del personal de salud, pues ante condiciones laborales precarias su situación de vulnerabilidad se incrementa ante la crisis pandémica.

21. Del anterior contexto, se puede asegurar que, en Colombia, antes de la llegada de la COVID-19, el sistema de salud ya se encontraba en cuidados intensivos. El alto número de acciones de tutela, 240.000 en el último año, los carteles que se han conformado para desangrar los dineros de la salud, las constantes quejas del personal de salud por falta de insumos 
necesarios y retrasos en el pago de salarios y/o honorarios, la deficiente prestación de servicios por parte de las principales empresas promotoras de salud y el bajo número de UCI disponibles ponen en un grave riesgo a la población colombiana ante la pandemia. Es decir, por la fragilidad del sector salud, Colombia encabezará la lista de los países con consecuencias más gravosas para su población. En particular, número de contagios y número de muertes por 1.000 habitantes.

\section{c. La COVID-19 en Colombia}

22. Como se dijo, Colombia adolece de un sistema de salud eficiente y que se encuentra en cuidados intensivos. Ante esta débil capacidad de respuesta del sector salud, el Gobierno adoptó como estrategia de mitigación de los efectos de la pandemia, un prolongado aislamiento preventivo obligatorio. Esta es una medida de intensidad fuerte que se justifica ante la fragilidad institucional en la garantía del derecho a la salud. Según informó la facultad de Economía de los Andes, para finales de mayo, nuestro país contaba con 6.364 camas UCI (Bermúdez, 2020). Las fuertes medidas de aislamiento fueron exitosas para demorar la llegada del pico de la pandemia. Sin embargo, se cuestionan decisiones contradictorias como las jornadas sin IVA en momentos en que el número de contagios comenzaba a expandirse entre los colombianos. Prácticamente, se ordenaron cuarentenas de manera ininterrumpida desde el 22 de marzo y hasta el 31 de agosto. Estas medidas también causaron efectos devastadores en la economía. Según el DANE, en julio de 2020 la tasa de desempleo alcanzó la cifra del 24,7\%. Si se compara con el mes de julio de 2019 el desempleo alcanzaba un 10,3\%. (DANE, Principales indicadores del mercado laboral, 2020)

23. Colombia registra, a 2 de septiembre, 624 mil personas contagiadas, de las cuales 470 mil se han recuperado y 20.052 han fallecido (MinSalud, 2020). Estas cifras lo ubican en el séptimo país con mayor número de contagios a nivel global y en el décimo con mayor número de muertes. Además, se puede proyectar que nuestro país siga escalando posiciones en este escalafón, pues Sudáfrica está a una diferencia de 7.000 contagios y Perú a una diferencia de 26.000. Incluso, de mantenerse en alto número de contagios diarios, nuestro país podría llegar a superar a Rusia, aun así a la fecha existe una diferencia de 343 mil contagios. El referido escenario, aunque parezca demasiado pesimista, no está alejado de la realidad. A partir del 1 de septiembre las medidas de cuarentena se flexibilizaron, pues de un escenario de aislamiento obligatorio se pasó a uno de aislamiento selectivo. Con la reapertura de las vías terrestres, fluviales y aéreas, y con la reactivación de los diferentes sectores de la economía, el virus seguirá en incremento.

24. Dentro de las justificaciones que se tuvieron para flexibilizar las medidas, están las de haber alcanzado el pico de la pandemia y el descenso en el número de contagios frente al número de pacientes recuperados. Sin embargo, de acuerdo con los registros del Ministerio de Salud, sorprende que el número de pruebas practicadas esté disminuyendo. Se toma como referencia la fecha en que se registró un mayor número de pruebas practicadas en lo corrido de la pandemia. El viernes 24 de julio se tomaron 40.110 pruebas. El viernes 31 de agosto 32.839 y el viernes 14 de agosto $29.682^{8}$. El 2 de septiembre se registraron 28.452 pruebas procesadas. Entonces, si a la fecha se presenta una pequeña reducción en el número de contagios por día, debe advertirse que también ha caído el número de pruebas realizadas. A 2 de septiembre el total de pruebas realizadas en Colombia asciende a 2.676.154 (Salud, 2020). Sin embargo, se resalta que, en la región, Colombia ${ }^{9}$ es el tercer país con mayor número de pruebas realizadas por 1.000 .000 de habitantes. Sólo es superado por Chile y Panamá.

8. La comparación se realizó dejando el mismo día en la semana, viernes, pues los fines de semana la tendencia es una disminución considerable del número de pruebas practicadas.

9. Chile tiene un total de 128.437, Panamá: 78571 y Colombia: 52.563. El número de pruebas se calcula en la proporción de 1.000 .000 de habitantes. Tomado de: https://www.ins.gov.co/Noticias/Paginas/coronaviruspcr.aspx. Visto: 2/09/2020. Hora: 08:51 pm. 
25. En conclusión, el panorama en Colombia no es muy esperanzador. Por una parte, a pesar de que su población apenas supera los 50 millones de habitantes, presenta un alto número de contagios $\mathrm{y}$, por la otra, el número de muertes diarias desde hace algunas semanas comienza a rondar las 300 por día. En la fecha, 2 de septiembre, se reportaron 296 fallecidos $^{10}$. En el contexto regional sólo es superado ampliamente por Brasil, en parte debido a la gran diferencia poblacional, y por un estrecho margen por Perú.

\section{EQUILIBRIO DE PODERES EN LA CONSTITUCIÓN POLÍTICA DE COLOMBIA. LA PANDEMIA EN TIEMPOS DE DESBALANCE INSTITUCIONAL}

26. El artículo 1 de la Constitución Política de 1991 define a Colombia como un "Estado social de derecho organizado en forma de República unitaria, descentralizada, con autonomía de sus entidades territoriales". La forma de gobierno que adoptó la Constitución fue, y ha sido por tradición, la forma presidencialista. Sin embargo, no se trata de un presidencialismo puro, aunque sí se conservan sus principales características. El presidente de la república se elige por voto popular directo de los ciudadanos, al igual que el vicepresidente de la república. Bajo este modelo, el presidente ejerce como jefe de gobierno, jefe de Estado y suprema autoridad de la administración (Constitución Política de Colombia, artículo 189). Esto significa que, en nuestra forma de gobierno, el legislativo no cuenta con mecanismos para otorgarle o retirarle su confianza al presidente.

27. El presidente de la República de Colombia es elegido por un período de 4 años ${ }^{11}$, y no existe posibilidad de reelección.

10. Tomado de: https://www.ins.gov.co/Noticias/ Paginas/coronavirus-pcr.aspx. Visto: 2/09/2020. Hora: 08:51 pm.

11. El artículo 190 de la Constitución Política establece que el presidente será elegido por una mayoría absoluta, pues se exige la mitad más 1 de los votos. En caso de que ninguno de los candidatos obtenga esta mayoría en primera vuelta, se realizará una segunda vuelta o
Sin embargo, durante el mandato de Álvaro Uribe Vélez se reformó el texto constitucional para permitirle ser candidato por segunda vez. En esa ocasión la Corte Constitucional, mediante sentencia C-1040 de 2005, declaró ajustada a la Constitución el Acto Legislativo 02 de 2004. Una vez Uribe ejercía su segundo mandato como presidente, se intentó una reforma constitucional vía referendo, para habilitar su tercera candidatura presidencial. No obstante, la Corte Constitucional, en sentencia C-141 de 2010, declaró que esta reforma sustituía el texto constitucional. En particular, se sustituía el principio de separación de poderes. Es decir que para 2010 se mantuvo la posibilidad de reelección por una única vez.

28. Con posterioridad se expidió el Acto Legislativo 02 de 2015, reforma de equilibrio de poderes, en el cual se puso fin a la posibilidad de reelección. El referido acto reformó el artículo 197 constitucional para prohibir la reelección, pero, además, le dio un carácter pétreo a esta cláusula. Se aclara que el constituyente colombiano no incorporó un listado expreso de cláusulas insustituibles en la carta política. Sin embargo, ha sido la jurisprudencia constitucional la que ha determinado aquellos elementos esenciales que no pueden ser objeto de sustitución constitucional $^{12}$. El carácter pétreo de esta disposición contenida en el artículo 197 deriva del hecho de que únicamente podrá ser reformada la prohibición de reelección "mediante referendo de iniciativa popular o asamblea constituyente". Se hace especial énfasis en que es el único enunciado normativo de la Constitución Política que tiene el reconocimiento expreso de un procedimiento más agravado de reforma. En otras palabras, todas las disposiciones constitucionales pueden ser reformadas a través de tres mecanismos: referendo de

$\overline{\text { balotaje propia de un sistema semi presidencialista }}$ como el francés.

12. Ver, entre otras las sentencias: C-551 de 2003, C-1040 de 2005, C-588 de 2009, C-141 de 2010, C-249 y C-1056 de 2012. En dichas providencias la Corte Constitucional determinó que principios como: separación de poderes, igualdad en el acceso a los cargos públicos y moralidad administrativa, entre otras, son elementos axiales del Estado social de derecho que no pueden ser materia de reforma constitucional. 
iniciativa popular, asamblea constituyente $\mathrm{y}$ acto legislativo, salvo este enunciado del artículo 197 que no puede ser objeto de reforma por el Congreso a través de acto legislativo.

29. La rama del poder legislativo en Colombia está conformada por un Congreso bicameral: Senado y Cámara de Representantes. El Congreso es elegido por voto popular directo de los ciudadanos para un período constitucional de 4 años. El Senado tiene una circunscripción nacional y está integrado por un total de 108 senadores. 100 son elegidos por la circunscripción nacional y 2 por la circunscripción nacional especial indígena, (Constitución Política, artículo 171, 1991) además, con carácter transitorio ${ }^{13}$ hay 5 curules para los ex combatientes de las Farc. La última curul puede otorgarse, en caso de que la acepte, para el candidato que obtuvo la segunda votación más alta en la elección presidencial (Ley 1909, 2018). La Cámara de Representantes se elige por circunscripción territorial y está integrada por 171 miembros. 161 elegidos por las circunscripciones territoriales, 4 de circunscripciones especiales: 2 por las comunidades afrodescendientes, 1 por las comunidades indígenas y 1 por la circunscripción internacional (Constitución Política, artículo 176, 1991); 5 curules ${ }^{14}$, con carácter transitorio, para los excombatientes de las Farc, y 1 curul para el segundo candidato más votado al cargo de vicepresidente, en caso de que sea aceptada (Ley 1909, 2018). Las dos cámaras, en relación con el procedimiento legislativo, cumplen funciones idénticas. Esto significa, que los proyectos de ley pueden iniciar su trámite de manera indistinta ante el Senado o la Cámara de Representantes.

30. La rama judicial en el sistema colombiano está integrada por distintas jurisdicciones. Las altas cortes conforman organismos de cierre en su jurisdicción sin que exista una jerarquía entre estas

13. Durante 2 períodos constitucionales: 2018 y 2022.

14. Al igual que en el Senado estos escaños tienen un carácter transitorio. corporaciones judiciales. Es decir que en Colombia no existe un solo órgano judicial que esté en la cima de la rama judicial. Así, el constituyente diseñó un modelo de 4 cortes. La jurisdicción ordinaria que tiene como cabeza a la Corte Suprema de Justicia está integrada por 23 magistrados. La jurisdicción contenciosa administrativa tiene como máximo tribunal al Consejo de Estado, integrado por 27 consejeros que cumplen función judicial y 4 consejeros que componen la Sala de Consulta y Servicio Civil. A los magistrados, tanto de la Corte Suprema de Justicia y del Consejo de Estado, se les elige por un sistema de cooptación (Constitución Política, artículo 231). Esto significa que ninguna otra rama del poder u organismo autónomo interviene en la elección de estos funcionarios judiciales, pues a partir de un listado que envía el Consejo Superior de la Judicatura cada Corporación elige de manera interna la plaza de magistrado que se encuentre vacante. A pesar de las fuertes críticas que pueda tener ese sistema decimonónico de elección, pues no garantiza el derecho político de igual acceso a los cargos públicos en una justa carrera meritocrática, es una manera de cuidar la independencia y autonomía judicial respecto a las demás ramas y órganos del poder público.

31. La jurisdicción constitucional tiene como cabeza a la Corte Constitucional que está integrada por 9 magistrados. Esta corporación fue creada por la Constitución Política de 1991 y debido a su función principal de control de constitucionalidad tiene un sistema de elección diferente. Las nueve plazas se eligen por el Senado, previo a la conformación de ternas. El presidente de la república postula los candidatos para 3 ternas, el Consejo de Estado otras 3 ternas, y las restantes son propuestas por la Corte Suprema de Justicia (Constitución Política, artículo 239). Como se ve, en la elección de estos 9 magistrados intervienen las 3 ramas del poder público. Sin embargo, el mecanismo indicado ha sido muy criticado por la politización que se puede dar de estos importantes cargos, fenómeno que no solo se predica de la elección del Senado sino también ante la ausencia de criterios 
objetivos, en la confección de las ternas por el presidente de la república y las otras altas cortes.

32. El Acto Legislativo 02 de 2015, equilibrio de poderes, deslindó el organismo de cierre de la jurisdicción disciplinaria del Consejo Superior de la Judicatura. Es decir, previo a esta reforma, el Consejo Superior estaba integrado por la Sala Administrativa y la Sala Jurisdiccional Disciplinaria. Ahora, esta última sala fue reemplazada por la Comisión Nacional de Disciplina Judicial. Aunque no ha entrado en funcionamiento, esta Comisión estará integrada por 7 magistrados. Estos funcionarios judiciales serán elegidos por el Congreso en pleno de 4 ternas enviadas por el Consejo Superior de la Judicatura y 3 por el presidente de la república (Constitución Política, artículo 257A). Según indica el texto constitucional, las ternas se deberán confeccionar previa convocatoria pública reglada. No obstante, estas convocatorias no están regidas por criterios objetivos, y, por lo general, el mecanismo que precede a la selección es una entrevista a los aspirantes. Esta sería una oportunidad para que se definan criterios objetivos en la confección de estas ternas, de tal manera que se garantice, por una parte, la imparcialidad de los ternados, y por la otra, las mejores cualidades de los aspirantes al cargo. El Consejo Superior de la Judicatura tiene como principal función el gobierno y administración de la rama judicial. Está integrado por 6 magistrados que se eligen: 2 por la Corte Suprema de Justicia, 1 por la Corte Constitucional y 3 por el Consejo de Estado (Constitución Política, artículo 254). Todos los magistrados de altas cortes en Colombia se eligen por un período constitucional de 8 años.

33. La Fiscalía General de la Nación también integra la rama judicial. La entidad es dirigida por el fiscal general de la nación, quien se elige para un período constitucional de 4 años por el pleno de la Corte Suprema de Justicia de terna conformada por el presidente de la república (Ibid., artículo 249). Su planta de personal es de 24.000 funcionarios, aproximadamente, de los cuales 17.000 cargos, en promedio, son ocupados en provisionalidad $^{15}$. La ausencia de concurso de méritos desde hace una década y media pone en grave riesgo la independencia e imparcialidad del organismo investigador.

34. Como se observa, aunque el constituyente de 1991 quiso dotar de independencia y autonomía a la rama judicial, es un hecho que el presidente de la república ejerce una injerencia directa en el nombramiento del fiscal general de la nación, en 3 de los 9 magistrados de la Corte Constitucional y en 3 de los 7 magistrados de la Comisión de Disciplina Judicial. Ahora, el Senado es quien elige a la totalidad de miembros de la Corte Constitucional y el Congreso en pleno todos los magistrados de la Comisión de Disciplina Judicial. Y, aunque la Corte Suprema de Justicia y el Consejo de Estado se eligen por el sistema de cooptación, dicho mecanismo no tiene como fundamento criterios objetivos para la elección. Esta ausencia de parámetros objetivos y reglamentados también ocurre en la elección que hacen las altas cortes de los magistrados del Consejo Superior de la Judicatura. En conclusión, el diseño constitucional colombiano no brinda elementos que garanticen la imparcialidad e independencia de los altos cargos de la rama judicial.

35. En otra orilla, sin que implique la configuración de una cuarta rama del poder público, se encuentran los organismos de control. La Contraloría de la República y el Ministerio Público conforman estos órganos independientes que tienen a su cargo la vigilancia y control de los diferentes organismos y entidades que conforman el Estado colombiano. A su vez, el Ministerio Público está integrado por la Procuraduría General de la Nación y la Defensoría del Pueblo. El contralor general de la república tiene a cargo la vigilancia fiscal sobre los recursos públicos del orden nacional

15. La información fue presentada por la accionante y corroborada por la Fiscalía General de la Nación en la acción de cumplimiento que se formuló con el objeto de que se convoquen a concurso los cargos que se encuentran ocupados en provisionalidad en la entidad. Sentencia de primera instancia proferida el 4 de marzo (Tribunal Administrativo de Cundinamarca, 2020). 
y se elige por un período de 4 años, sin posibilidad de reelección, por el Congreso en pleno, por mayoría absoluta. Su período coincide con el del presidente de la república. Y, para su elección se debe integrar una lista de elegibles producto de convocatoria que realiza el mismo Congreso ${ }^{16}$ (Ibid., artículo 267). El procurador general de la nación ejerce la vigilancia de la conducta oficial de los servidores públicos, vigila el cumplimiento del ordenamiento jurídico, protege los derechos humanos, con el auxilio del defensor del pueblo, y defiende los intereses de la sociedad (Ibid., artículo 277). El alto funcionario es elegido por el Senado para un período de 4 años de terna enviada por el presidente de la república, Corte Suprema de Justicia y Consejo de Estado (Ibid., artículo 276). El Defensor del Pueblo, quien tiene a su cargo la promoción, ejercicio y divulgación de los derechos humanos (Ibid., artículo 282), es elegido por la Cámara de Representantes de terna elaborada por el presidente de la república (Ibid. Artículo 281).

36. Los organismos de control tampoco están a salvo de la injerencia de las cabezas de las ramas del poder público. El presidente de la república propone la terna para elegir defensor del pueblo, y uno de los ternados para el cargo de procurador general de la nación. El Congreso en pleno tiene a su cargo la elección del contralor general de la república, su cámara alta elige al procurador y su cámara baja al defensor. La Corte Suprema de Justicia y el Consejo de Estado envían un ternado para que se elija al procurador general. Esto implica que las cabezas de los órganos de control accedan al cargo por criterios políticos más que por criterios técnicos. Se insiste en el carácter técnico de estas entidades, en consecuencia, su elección no debería estar supeditada a las decisiones discrecionales o políticas del presidente de la república, Congreso o altas corporaciones. El sistema mencionado debilita el principio democrático, pues las cabezas de dichas entidades son elegidas por un órgano derivado y no por el constituyente

16. La Ley 1904 de 2018 reguló el procedimiento de selección del Contralor General de la República. primario. De acuerdo con lo anterior se encuentra que el Estado colombiano ha relegado a un segundo plano a la Comisión Nacional del Servicio Civil, órgano creado por la Constitución del 91, en relación con la elección de los altos funcionarios. Quizás un mejor mecanismo para garantizar la independencia y autonomía de los magistrados de las altas cortes y de las cabezas de los órganos de control sea el concurso de méritos. Por tal razón, la CNSC debería tener un rol principal, pues fue la entidad que la Constitución creó para liderar los procesos de selección objetiva en nuestro país.

37. En tiempos de pandemia, el Estado colombiano está pagando un alto precio por esas ligerezas constitucionales en relación con la elección de los altos funcionarios. El presidente, Iván Duque, comenzó su período presidencial el 7 de agosto de 2018. El contralor general de la república inició su período el 1 de septiembre del mismo año, y aunque hubo una convocatoria pública para su elección, fue decisivo el respaldo político de las bancadas de gobierno ${ }^{17}$. Incluso, es un funcionario que siempre ha estado ocupando altos cargos, a los que se accede por razones políticas, mas no técnicas ${ }^{18}$. El fiscal general de la nación comenzó a ejercer su cargo a partir del 13 de febrero de 2020 (Fiscalía General de la Nación, 2020). Francisco Barbosa es del círculo cercano del presidente Duque, y fue alto consejero presidencial para los Derechos Humanos y Asuntos Internacionales de su gobierno. El defensor del pueblo, Carlos Camargo, inició su período el 01 de septiembre de 2020 (Espectador, 2020). El alto funcionario, al igual que el contralor, venía de ocupar el cargo de director de la Federación de Departamentos y para

17. “[...] Córdoba, luego de ser elegido este lunes en votación del Congreso, ingresó al recinto antecedido por el expresidente y líder del Partido Liberal, César Gaviria, quien le abrió paso para que lograra avanzar entre el cúmulo de senadores que se ubicaron a lo largo del pasillo central para recibirlo y felicitarlo. El nuevo Contralor, una vez llegó al atrio, agradeció a Gaviria, Pastrana, Vargas Lleras y a Uribe por el apoyo que le brindaron en el proceso para su elección [...]" (El Tiempo, 2018).

18. Córdoba viene de ocupar el cargo de director ejecutivo de la Federación Nacional de Departamentos (FND) (Portafolio, 2018). 
materializar su aspiración logró consolidar apoyos de diferentes fuerzas políticas en la Cámara ${ }^{19}$. Por último, el pasado $27 \mathrm{de}$ agosto, el Senado eligió como procuradora general de la nación a Margarita Cabello (El Tiempo, 2020). La procuradora electa ocupó el cargo de ministra de justicia hasta el 18 de agosto de 2020 (El Espectador, 2020). En síntesis, Colombia se encuentra sumida en una crisis de institucionalidad, pues el presidente Duque ha logrado influenciar de manera directa en la elección de las cabezas de los organismos de control y de la Fiscalía General de la Nación.

38. Bajo este contexto, nuestro país atraviesa no solo la crisis de la emergencia sanitaria causada por la COVID-19, sino también se ve enfrentado a una crisis institucional sin precedentes que genera un desbalance en el equilibrio de poderes. Dicha conclusión también es compartida por Transparencia Internacional - Capítulo Colombia. Según el mentado organismo existe "profunda preocupación por la creciente concentración del poder en el Presidente de la República". Premisa sustentada en la cercanía del gobierno con las mayorías del Congreso, las facultades como legislador transitorio en el Estado de excepción, el debilitamiento de las autoridades locales frente al gobierno central, acciones cuestionables frente a la afectación de libertades de expresión, participación ciudadana y acceso a la información y la pérdida de autonomía de los órganos de control. Hace especial énfasis en la elección de "personas cercanas al gobierno para dirigir la Fiscalía General de la Nación, la Procuraduría General de la Nación y la Defensoría del Pueblo" (Transparencia por Colombia, 2020).

39. En razón de lo anterior, es posible considerar que el Estado de excepción que vive Colombia, que justamente coincidió

19. “[...] La elección de Camargo ya estaba más que cantada. Esta semana los representantes del Partido Liberal, Conservador, Cambio Radical y Centro Democrático y sus alianzas de gobierno con Colombia Justa Libres y Mira, habían manifestado su respaldo a Camargo. El día de ayer, La U concertó que sus 25 representantes también lo apoyarían. Con esto ya estaba más que segura su elección [...] (Semana, 2020). con un año en el que se han elegido 3 altos funcionarios (fiscal general de la nación, procurador general de la nación y defensor del pueblo) altera el equilibrio de poderes al punto de transitar de un presidencialismo hacia un hiperpresidencialismo, por lo menos, de carácter transitorio. No obstante, preocupa la cooptación que ha hecho el Ejecutivo de los jefes de los organismos de control y de la Fiscalía General de la Nación, pues esto podría ser un indicador de una prolongación del hiperpresidencialismo. Es decir que esa visa expansiva de poderes del Ejecutivo no solo estaría sujeta a la duración del Estado de emergencia, sino que con personas cercanas al presidente en los altos cargos podría presentarse durante todo el mandato. De tal modo, el autor sostiene que un gobierno hiperpresidencialista no solo se produce por una reforma constitucional que amplíe el período presidencial, pues como se dijo Colombia estaría a salvo de esta modalidad (párrafo 28), sino también por la exacerbada concentración de poder dentro de un solo mandato presidencial.

\section{ESTADO DE EXCEPCIÓN EN COLOMBIA: HIPERPRODUCCIÓN NORMATIVA DEL EJECUTIVO VERSUS DÉBIL CONTROL CONSTITUCIONAL}

\section{a. Los estados de excepción en el ordenamiento constitucional}

40. El constituyente colombiano de 1991 determinó el contenido básico de los tres estados de excepción que pueden ser declarados. En consecuencia, estableció la posibilidad para que el presidente de la república, con la firma de todos los ministros, pueda declarar los estados de excepción de: guerra exterior, conmoción interior y emergencia económica, social y ecológica. Estos escenarios de excepcionalidad tienen algunas diferencias sustanciales entre sí. El Estado de guerra exterior se justifica para "defender la soberanía y atender los requerimientos de la guerra". En dicho evento, el Gobierno puede cumplir función legislativa transitoria que implica la suspensión de aquellas leyes que sean incompatibles con el Estado de guerra 
(Constitución Política, artículo 212). El Estado de conmoción interior se justifica en "la grave perturbación del orden público que tenga la fuerza de atentar de manera inminente contra la estabilidad institucional, la seguridad del Estado o la convivencia ciudadana". De igual forma, se señaló la posibilidad de que el Gobierno tenga facultades para expedir decretos legislativos, los cuales podrán suspender aquellas leyes que sean incompatibles con la conmoción interior. Además, para este caso, el constituyente impuso un límite temporal de 90 días, prorrogable hasta por dos períodos iguales (Constitución Política, artículo 213).

41. El tercer estado de excepción podrá ser declarado cuando se vea amenazado en "forma grave e inminente el orden económico, social y ecológico". En este escenario, el límite temporal se fijó en un período de 30 días, con la posibilidad de ser prorrogado por dos períodos más. En vigencia del estado de excepción, el presidente, con la firma de todos los ministros, podrá dictar decretos con fuerza material de ley, cuyo propósito sea conjurar la situación de crisis. La actividad legislativa de excepción deberá guardar "relación directa y específica con el Estado de emergencia". Dentro de estas competencias, incluso, se podrán crear o modificar tributos con carácter transitorio. El Congreso realizará un examen de la conveniencia y oportunidad de las medidas adoptadas y de las causas que motivaron el estado de emergencia. El constituyente señaló de manera expresa la prohibición de desmejora de los derechos sociales de los trabajadores por las medidas legislativas adoptadas por el Gobierno (Constitución Política, artículo 215).

42. Con sujeción al marco constitucional, una vez se declara el estado de excepción, mediante decreto firmado por el presidente y todos los ministros del Gobierno Nacional, se desprende la función de control jurisdiccional de la actividad legislativa y reglamentaria de carácter excepcional. Por una parte, a la Corte Constitucional le corresponde adelantar el control automático de constitucionalidad sobre los decretos legislativos dictados en el marco del estado de excepción (Constitución Política, artículo 241-7). La competencia referida incluye la revisión del decreto que declara el Estado de excepción ${ }^{20}$. Y, por la otra, la jurisdicción de lo contencioso administrativo tiene la competencia para realizar el control inmediato de legalidad sobre la actividad reglamentaria expedida con fundamento en los decretos legislativos dictados en el marco del Estado de excepción (Ley 137 de 1994). Al interior de la jurisdicción de lo contencioso administrativo, el Consejo de Estado conocerá de aquellos actos que emanen de "autoridades nacionales" y los tribunales administrativos de los actos expedidos por "autoridades territoriales" (Ley 1474 de 2011).

43. Los estados de excepción son, por naturaleza, una fuente que desequilibra el principio de frenos y contrapesos, pues permite una ampliación de las competencias del Ejecutivo. Bajo tal premisa, el control jurisdiccional emerge como un mecanismo eficaz para controlar ese superávit normativo dictado en desarrollo del Estado de excepción. En la práctica, es como si se colocara un gran paréntesis al ordenamiento jurídico infra constitucional que sea contrario a los efectos jurídicos derivados de la normativa propia del estado de excepción. Por esta razón, tanto la Corte Constitucional, como el Consejo de Estado y los tribunales administrativos desempeñan un papel protagónico para evitar el desquicio del sistema de fuentes del derecho.

\section{b. Hiperproducción normativa del Ejecutivo colombiano vs débil control constitucional}

44. El Gobierno nacional declaró el Estado de emergencia social, económica y ecológica mediante el Decreto 417 del 17 de marzo 2017. Esta declaratoria estuvo vigente por el término de 30 días. Además, dictó una

20. En la Corte Constitucional ha sido pacífica la línea jurisprudencial, según la cual contra el decreto que declare el Estado de excepción procede el control automático de constitucionalidad. La sentencia C-004 de 1992 declaró constitucional el Decreto 333 de 1992 "Por el cual se declara el Estado de Emergencia Social". En vigencia de la Constitución Política de 1991, este caso se registra como el primer control de constitucionalidad a un decreto declaratorio del Estado de excepción. 
prórroga del Estado de excepción mediante el Decreto 637 del 6 de mayo de 2020, de igual forma, por el término de 30 días. Dentro de estos dos estados de excepción, el poder Ejecutivo Nacional expidió 115 decretos legislativos. Como se indicó supra, estos decretos tienen la fuerza para suspender la legislación ordinaria. Asimismo, el Ministerio de Salud y Protección Social ha declarado la emergencia sanitaria en tres ocasiones. La primera, con Resolución 385 del 12 de marzo de 2020 con una vigencia al 30 de mayo. La segunda, con Resolución 844 del 26 de mayo con una vigencia al 31 de agosto. Y, la tercera, con Resolución 1426 del 26 de agosto con vigencia hasta el 30 de noviembre. Por último, y en uso de sus facultades constitucionales ordinarias, el presidente de la república ha dictado diversos decretos por los cuales se ha ordenado el aislamiento preventivo de carácter obligatorio. El primero de estos decretos fue el 457 del 22 de marzo de 2020.

45. Vale la pena tener en cuenta la reflexión que hace el profesor Uprimny frente al excesivo número de decretos legislativos. Según él, los 115 decretos expedidos en tan solo dos meses equivalen, aproximadamente, a una tercera parte de la totalidad, 386, de decretos legislativos expedidos en 20 años (Uprimny, 2020). Los decretos legislativos expedidos por el Gobierno han versado sobre diversas materias. Por lo tanto, es posible considerar que un gran número de estos decretos no eran necesarios o no guardaban relación directa con la situación de crisis causada por el virus COVID-19. Para sustentar esta premisa, a continuación, se presentarán aquellos decretos los cuales reflejan ese carácter hiperpresidencialista por abuso de las facultades legislativas durante el Estado de excepción.

46. En la siguiente tabla figuran 34 decretos legislativos que, bajo esta lógica, representan un abuso de las facultades del legislador excepcional. Se aclara que las razones sustentadas son independientes de la decisión adoptada por la Corte Constitucional, pues en la mayoría de los casos los decretos se declararon ajustados a la Constitución. Sin embargo, en varios de los decretos analizados se comparten algunos argumentos expuestos en los salvamentos de voto que, se reitera, no representan la decisión mayoritaria del alto tribunal.

\section{Tabla 1. Análisis decretos legislativos}

\begin{tabular}{|l|l|l|l|}
\hline N. & D.L. & $\begin{array}{c}\text { OBJETO - DECISIÓN } \\
\text { CORTE CONSTITUCIONAL }\end{array}$ & \multicolumn{1}{c|}{$\begin{array}{c}\text { RAZONES DE ABUSO NORMATIVO POR PARTE } \\
\text { DEL LEGISLADOR EXCEPCIONAL }\end{array}$} \\
\hline 1 & $\begin{array}{l}439 \mathrm{del} \\
20 / 03\end{array}$ & $\begin{array}{l}\text { Suspensión desembarque con } \\
\text { fines de ingreso o conexión } \\
\text { en territorio colombiano, de } \\
\text { pasajeros procedentes del } \\
\text { exterior por vía aérea. }\end{array}$ & $\begin{array}{l}\text { A pesar de que es una medida que responde a la finalidad del actual } \\
\text { estado de excepción, dichas facultades ya se contemplaban en el or- } \\
\text { denamiento jurídico ordinario. La Ley 12 de 1947 "Convención sobre } \\
\text { Aviación Civil internacional de 1944" (artículos 13 y 14) y la Ley } 9 \text { de } \\
\text { 1979 (artículo 489) le otorgan al Ministerio de Salud las competencias } \\
\text { como autoridad para realizar la vigilancia y controles epidemiológicos. } \\
\text { En los salvamentos parciales de voto de la sentencia, los magistrados } \\
\text { Fajardo, Pardo y Rojas hacen mención a la falta de necesidad jurídica, } \\
\text { es decir, que con la normativa ordinaria se podría haber reglamenta- } \\
\text { do la materia. (Corte Constitucional, C-157, 2020). }\end{array}$ \\
\hline
\end{tabular}

a. Decreto Legislativo. 


\begin{tabular}{|c|c|c|c|}
\hline $\mathrm{N}^{\circ}$. & D.L. ${ }^{a}$ & $\begin{array}{l}\text { OBJETO - DECISIÓN } \\
\text { CORTE CONSTITUCIONAL }\end{array}$ & $\begin{array}{l}\text { RAZONES DE ABUSO NORMATIVO POR PARTE } \\
\text { DEL LEGISLADOR EXCEPCIONAL }\end{array}$ \\
\hline 2 & $\begin{array}{l}444 \text { del } \\
20 / 03\end{array}$ & $\begin{array}{l}\text { Creación del fondo de } \\
\text { mitigación de emergencias } \\
\text { FOME. } \\
\text { EXEQUIBLE } \\
\text { C-194 }\end{array}$ & $\begin{array}{l}\text { El FOME se financia con recursos de dos fondos: FONPET (Fondo de } \\
\text { Pensiones Territoriales) y FAE (Fondo de Ahorro y Estabilización). No } \\
\text { es clara la relación de conexidad con el Estado de excepción, pues } \\
\text { pareciera que no resuelve una problemática del sector salud, sino } \\
\text { que busca asegurar liquidez en la economía nacional a través de } \\
\text { colocación de dinero y préstamos a bancos comerciales. Esto genera } \\
\text { tres graves problemas. El primero, en relación con la vulneración de } \\
\text { la autonomía del banco central, en virtud del artículo } 371 \text { superior, } \\
\text { porque la función de "prestamista de última instancia y banquero } \\
\text { de los establecimientos de crédito" está en cabeza del Banco de la } \\
\text { República. Por lo tanto, se estaría suplantando la función del banco } \\
\text { emisor. El segundo: esta medida no responde de manera inmediata a } \\
\text { conjurar la crisis económica. No inyecta recursos ni al sector salud ni } \\
\text { a la población que resultó más afectada. Así, resulta ser una medida } \\
\text { con propósitos a mediano y largo plazo, incluso en favor de sectores } \\
\text { económicos que no eran vitales para la atención de la crisis, como } \\
\text { el financiero. Quizás la renta básica hubiese sido una medida más } \\
\text { eficiente para conjurar la crisis. El tercero, no se exploraron otras } \\
\text { vías, como la utilización de reservas internacionales, que para agosto } \\
\text { de } 2020 \text { ascienden a } 57.184 \text { millones de dólares (Banrep, 2020), } \\
\text { lo cual hubiese evitado el aumento de deuda pública. Además, en } \\
\text { la sentencia se presentaron salvamentos de voto que apoyaban la } \\
\text { tesis de declaratoria de inexequibilidad del decreto. La magistrada } \\
\text { Cristina Pardo hizo especial énfasis en la contradicción con el inciso } 5 \\
\text { del artículo } 48 \text { constitucional, toda vez que no se podían utilizar los } \\
\text { recursos de la seguridad social para fines diferentes a ella. De igual } \\
\text { modo, se desconoce la autonomía territorial de las entidades. El } \\
\text { magistrado Rojas consideró que el decreto desconoce derechos como } \\
\text { el de seguridad social, prohibición de regresividad de los derechos } \\
\text { sociales y las reglas específicas sobre modificaciones presupuestales } \\
\text { en los estados de excepción, como también el principio de autonomía } \\
\text { territorial (Corte Constitucional C-194, 2020). }\end{array}$ \\
\hline 3 & $\begin{array}{l}461 \text { del } \\
22 / 03\end{array}$ & $\begin{array}{l}\text { Autorización temporal a } \\
\text { gobernadores y alcaldes para } \\
\text { reorientación de rentas y } \\
\text { reducción de tarifas de im- } \\
\text { puestos territoriales. } \\
\text { EXEQUIBLE } \\
\text { C-169 }\end{array}$ & $\begin{array}{l}\text { Se da una fuerte injerencia en el principio de autonomía territorial, } \\
\text { en especial, en las facultades de las asambleas departamentales y } \\
\text { concejos municipales, pues son los organismos que tienen asignada } \\
\text { esta competencia en virtud de las disposiciones constitucionales. En } \\
\text { la sentencia que resolvió el control automático de constitucionalidad, } \\
\text { los magistrados Diana Fajardo, Cristina Pardo y Alberto Rojas salvaron } \\
\text { su voto. Este último, lo hizo de manera parcial (Corte Constitucional, } \\
\text { C-169, 2020). }\end{array}$ \\
\hline 4 & $\begin{array}{l}476 \text { del } \\
25 / 03\end{array}$ & $\begin{array}{l}\text { Prevención, diagnóstico y } \\
\text { tratamiento del COVID-19. } \\
\text { INEXEQUIBLE PARCIAL artícu- } \\
\text { los } 1 \text { y } 2 \text {. } \\
\text { C-155 }\end{array}$ & $\begin{array}{l}\text { En relación con el otorgamiento de facultades al Ministerio de Salud } \\
\text { y Proyección Social y al Invima, la Corte Constitucional determinó que } \\
\text { dichas competencias ya se encontraban previstas en el ordenamiento } \\
\text { ordinario (Corte Constitucional, C-155, 2020). Por lo tanto, no era } \\
\text { necesario incorporar las referidas medidas reglamentarias en un de- } \\
\text { creto legislativo. Los magistrados Carlos Bernal y José Fernando Reyes } \\
\text { salvaron su voto frente a la declaratoria de inexequibilidad parcial de } \\
\text { la sentencia. }\end{array}$ \\
\hline 5 & $\begin{array}{l}482 \text { del } \\
26 / 03\end{array}$ & $\begin{array}{l}\text { Medidas servicio público } \\
\text { transporte e infraestructura. } \\
\text { EXEQUIBLE } \\
\text { C-185 }\end{array}$ & $\begin{array}{l}\text { La presente investigación comparte los argumentos expresados en } \\
\text { los salvamentos de voto de los magistrados Diana Fajardo y Alberto } \\
\text { Rojas, quienes consideraron que las medidas no superan el juicio de } \\
\text { necesidad, por cuanto podían derivar del ordenamiento jurídico ordi- } \\
\text { nario. En consecuencia, el legislador excepcional excedió sus límites } \\
\text { al dictar una normativa que no era necesaria (Corte Constitucional, } \\
\text { C-185, 2020). }\end{array}$ \\
\hline
\end{tabular}




\begin{tabular}{|c|c|c|c|}
\hline $\mathrm{N}^{\circ}$. & D.L. $^{a}$ & $\begin{array}{l}\text { OBJETO - DECISIÓN } \\
\text { CORTE CONSTITUCIONAL }\end{array}$ & $\begin{array}{c}\text { RAZONES DE ABUSO NORMATIVO POR PARTE } \\
\text { DEL LEGISLADOR EXCEPCIONAL }\end{array}$ \\
\hline 6 & $\begin{array}{l}492 \text { del } \\
28 / 03\end{array}$ & $\begin{array}{l}\text { Se establecen medidas para } \\
\text { el fortalecimiento del Fondo } \\
\text { Nacional de Garantías. } \\
\text { EXEQUIBLE } \\
\text { C-200 }\end{array}$ & $\begin{array}{l}\text { No era necesario expedir un decreto con fuerza material de ley, pues } \\
\text { el presidente podía hacer estos traslados a través de sus facultades } \\
\text { ordinarias, previstas en el artículo } 189 \text { de la Constitución Política. El } \\
\text { magistrado Alberto Rojas solicitó la declaratoria de inexequibilidad } \\
\text { de la totalidad del decreto en su salvamento de voto a la sentencia } \\
\text { (Corte Constitucional, C-200, 2020). }\end{array}$ \\
\hline 7 & $\begin{array}{l}507 \text { del } \\
01 / 04\end{array}$ & $\begin{array}{l}\text { Se adoptan medidas para } \\
\text { favorecer el acceso de los } \\
\text { hogares más vulnerables a } \\
\text { productos básicos. } \\
\text { EXEQUIBLE } \\
\text { C-178 }\end{array}$ & $\begin{array}{l}\text { Aunque es una medida que guarda conexidad con la crisis por la } \\
\text { paralización de varios sectores de la economía, en especial, aquellos } \\
\text { hogares colombianos que viven del diario, no era necesario expedir } \\
\text { una legislación de carácter extraordinario. Tal y como lo plasmaron los } \\
\text { magistrados Diana Fajardo, Cristina Pardo y Alberto Rojas en sus salva- } \\
\text { mentos de voto el decreto no supera el juicio de necesidad jurídica, } \\
\text { por tanto, en el ordenamiento ordinario el presidente ya contaba con } \\
\text { estas facultades (Corte Constitucional, C-178, 2020). }\end{array}$ \\
\hline 8 & $\begin{array}{l}512 \mathrm{del} \\
02 / 04\end{array}$ & $\begin{array}{l}\text { Se autoriza a los gobernado- } \\
\text { res y alcaldes para realizar } \\
\text { movimientos presupuestales. } \\
\text { EXEQUIBLE } \\
\text { C-186 }\end{array}$ & $\begin{array}{l}\text { Aplican los mismos argumentos del Decreto } 461 \text { (casilla } 3 \text { de la tabla } \\
\text { 1). Se vulnera el principio de autonomía territorial, en especial, las } \\
\text { facultades de las asambleas departamentales y concejos municipales. } \\
\text { De nuevo, los magistrados Diana Fajardo, Cristina Pardo y Alberto } \\
\text { Rojas hicieron esta salvedad frente a la decisión mayoritaria (Corte } \\
\text { Constitucional, C-186, 2020). }\end{array}$ \\
\hline 9 & $\begin{array}{l}513 \text { del } \\
02 / 04\end{array}$ & $\begin{array}{l}\text { Proyectos de inversiones } \\
\text { públicas susceptibles de ser } \\
\text { financiadas con recursos del } \\
\text { Sistema General de Regalías. } \\
\text { EXEQUIBLE } \\
\text { C-254 }\end{array}$ & $\begin{array}{l}\text { Del decreto mencionado se declararon inexequibles una expresión } \\
\text { del inciso único del artículo } 5 \text { y el parágrafo } 2 \text { de este mismo artículo, } \\
\text { toda vez que hacían relación al pago del servicio de alumbrado públi- } \\
\text { co con recursos del Sistema General de Regalías. El autor considera } \\
\text { razonable la declaratoria de inexequibilidad que se sustentó en la falta } \\
\text { de conexidad con los motivos que llevaron a declarar la crisis, y el de } \\
\text { contradicción directa con las disposiciones constitucionales que seña- } \\
\text { lan el principio de autonomía territorial. El magistrado Carlos Bernal } \\
\text { salvó el voto respecto de la declaratoria de inexequibilidad (Corte } \\
\text { Constitucional, C-254, 2020). }\end{array}$ \\
\hline $\begin{array}{l}10, \\
11 \\
12 \\
13\end{array}$ & $\begin{array}{l}519 \text { del } \\
05 / 04 \\
522 \text { del } \\
06 / 04 \\
571 \text { del } \\
15 / 04 \\
572 \text { del } \\
15 / 04\end{array}$ & $\begin{array}{l}\text { Se adiciona el Presupuesto } \\
\text { General de la Nación Vigencia } \\
\text { fiscal y efectúa liquidación. } \\
\text { EXEQUIBLE PARCIAL } \\
\text { C-170, C- } 212, \text { C- } 215 \text { y C-206. }\end{array}$ & $\begin{array}{l}\text { La Corte Constitucional declaró la inexequibilidad de los artículos } \\
3^{\circ}, 4^{\circ} \text { y } 5^{\circ} \text {, liquidación del presupuesto, por no superar el juicio de } \\
\text { necesidad jurídica. La referida declaratoria aplica para todos los de- } \\
\text { cretos legislativos que se expidieron sobre el presupuesto general. Al } \\
\text { igual que la posición mayoritaria de la Corte, el autor considera que } \\
\text { dicha liquidación se podía hacer como desarrollo de las facultades } \\
\text { ordinarias del presidente, sin necesidad de expedir una legislación de } \\
\text { carácter extraordinario. Los magistrados Carlos Bernal, Luis Guillermo } \\
\text { Guerrero, y Antonio Lizarazo salvaron su voto, porque consideraron } \\
\text { que el decreto era exequible en su totalidad. (Corte Constitucional, } \\
\text { C-170, C-212 y C-215, 2020). }\end{array}$ \\
\hline $\begin{array}{l}14 \\
y \\
15\end{array}$ & $\begin{array}{l}537 \text { del } \\
12 / 04 \text { y } \\
440 \text { del } \\
20 / 03\end{array}$ & $\begin{array}{l}\text { Se adoptan medidas en mate- } \\
\text { ria de contratación estatal. } \\
\text { EXEQUIBLES } \\
\text { C- } 162 \text { y C-181 }\end{array}$ & $\begin{array}{l}\text { Aunque estos decretos fueron declarados exequibles en su totalidad } \\
\text { (Corte Constitucional, C-162 y C-181, 2020), a juicio del investigador } \\
\text { la medida contemplada en el artículo } 7 \text { "contratación de urgencia" } \\
\text { no superaba el juicio de necesidad jurídica. El ordenamiento ordina- } \\
\text { rio, Ley } 80 \text { de } 1993 \text { artículo 42, contempla los presupuestos bajo los } \\
\text { cuales se puede adelantar la contratación por urgencia manifiesta. } \\
\text { Dentro de dichos presupuestos, uno de ellos corresponde a una de- } \\
\text { claratoria del Estado de excepción. En suma, para realizar la contrata- } \\
\text { ción bajo esta modalidad, solo bastaba con la expedición del decreto } \\
\text { que declarara el Estado de excepción, es decir, no era necesaria una } \\
\text { norma adicional incluida en un decreto legislativo. }\end{array}$ \\
\hline
\end{tabular}




\begin{tabular}{|c|c|c|c|}
\hline $\mathrm{N}^{\circ}$. & D.L. $^{a}$ & $\begin{array}{l}\text { OBJETO - DECISIÓN } \\
\text { CORTE CONSTITUCIONAL }\end{array}$ & $\begin{array}{l}\text { RAZONES DE ABUSO NORMATIVO POR PARTE } \\
\text { DEL LEGISLADOR EXCEPCIONAL }\end{array}$ \\
\hline 16 & $\begin{array}{l}552 \text { del } \\
15 / 04\end{array}$ & $\begin{array}{l}\text { Fondo de Riesgos Laborales } \\
\text { prestará a la Nación hasta el } \\
80 \% \text { de su saldo acumulado, } \\
\text { en la medida en que vayan } \\
\text { siendo requeridos por el } \\
\text { FOME. } \\
\text { EXEQUIBLE C- } 240\end{array}$ & $\begin{array}{l}\text { Se reiteran los argumentos expuestos frente al decreto 444, (casilla 2), } \\
\text { pues contradice el artículo } 48 \text { constitucional. Los magistrados Cristina } \\
\text { Pardo y Alberto Rojas expresaron las mismas razones para salvar su } \\
\text { voto en relación con la sentencia que declaró la exequibilidad de la } \\
\text { creación del FOME, decreto } 444 \text { (Corte Constitucional, C-240, 2020). }\end{array}$ \\
\hline 17 & $\begin{array}{l}554 \mathrm{del} \\
15 / 04\end{array}$ & $\begin{array}{l}\text { Nuevos porcentajes mínimos } \\
\text { de programación nacional. } \\
\text { EXEQUIBLE PARCIAL } \\
\text { C-247 }\end{array}$ & $\begin{array}{l}\text { La Corte Constitucional declaró inexequible el artículo } 1 \text { del referido } \\
\text { decreto, porque i) aunque la pandemia impedía el desarrollo de nue- } \\
\text { vos productos de televisión, no impedía la trasmisión de programas } \\
\text { nacionales, ii) el } 20 \% \text { como cuota de pantalla nacional no se justificó, } \\
\text { iii) reducir la cuota de pantalla nacional afectaba los derechos a la } \\
\text { identidad y cultura nacional. Los magistrados Carlos Bernal y Antonio } \\
\text { Lizarazo salvaron su voto respecto de la declaratoria parcial de incons- } \\
\text { titucionalidad (Corte Constitucional, C-247, 2020). }\end{array}$ \\
\hline 18 & $\begin{array}{l}558 \text { del } \\
15 / 04\end{array}$ & $\begin{array}{l}\text { Medidas en el ámbito del } \\
\text { Sistema General de Pensiones, } \\
\text { para brindar mayor liquidez } \\
\text { a los empleadores y trabaja- } \\
\text { dores y proteger a los pen- } \\
\text { sionados bajo la modalidad } \\
\text { de retiro programado, que } \\
\text { reciben un SMLV. } \\
\text { INEXEQUIBLE } \\
\text { C-258 }\end{array}$ & $\begin{array}{l}\text { La Corte Constitucional declaró inexequible el decreto por las siguien- } \\
\text { tes razones: i) desmejora los derechos sociales de los trabajadores } \\
\text { con expectativa de pensiones superiores a un salario mínimo, ii) } \\
\text { dispone de recursos destinados a la financiación de las pensiones } \\
\text { para fines distintos a ellas, y iii) no asegura la sostenibilidad finan- } \\
\text { ciera del sistema en relación con el reconocimiento de las semanas } \\
\text { correspondientes a los períodos de abril y mayo del presente año, } \\
\text { para efectos de la pensión mínima en el Régimen de Ahorro Individual } \\
\text { con Solidaridad. Los magistrados Luis Guillermo Guerrero y Alejandro } \\
\text { Linares salvaron su voto y el magistrado Carlos Bernal presentó salva- } \\
\text { mento parcial de voto, pues, a su juicio, era exequible la primera parte } \\
\text { del decreto (Corte Constitucional, C-258, 2020). }\end{array}$ \\
\hline 19 & $\begin{array}{l}559 \mathrm{del} \\
15 / 04\end{array}$ & $\begin{array}{l}\text { Subcuenta temporal para la } \\
\text { contención y mitigación de la } \\
\text { emergencia para financiar la } \\
\text { provisión de bienes, servicios } \\
\text { y obras requeridas para conte- } \\
\text { ner, mitigar y evitar la exten- } \\
\text { sión de los efectos adversos } \\
\text { derivados de la pandemia. } \\
\text { EXEQUIBLE } \\
\text { C-210 }\end{array}$ & $\begin{array}{l}\text { La referida normativa creó una burocracia innecesaria. Por una par- } \\
\text { te, ya existía un marco normativo, Ley } 1523 \text { de } 2012 \text {, que regula la } \\
\text { gestión del riesgo en Colombia. Y, por la otra, y tal como lo expresó } \\
\text { el magistrado Alberto Rojas en su salvamento de voto, esto gene- } \\
\text { ra una duplicidad de funciones frente a una misma tarea (Corte } \\
\text { Constitucional, C-210, 2020). En este orden de ideas, el decreto no } \\
\text { satisface el juicio de necesidad jurídica, toda vez que la normativa } \\
\text { de gestión del riesgo permite actuar en situaciones que requieren } \\
\text { respuestas urgentes e inminentes. A pesar de la declaratoria de exe- } \\
\text { quibilidad que profirió nuestro Tribunal Constitucional, los magistra- } \\
\text { dos Alberto Rojas y Cristina Pardo salvaron su voto. Esta última solo } \\
\text { de manera parcial, en relación con el parágrafo } 1 \text { del artículo } 3 \text { del } \\
\text { Decreto } 559 \text { de } 2020 \text {. }\end{array}$ \\
\hline 20 & $\begin{array}{l}567 \text { del } \\
15 / 04\end{array}$ & $\begin{array}{l}\text { Facultades a las procuradurías } \\
\text { judiciales de familia como } \\
\text { autoridades jurisdiccionales } \\
\text { para adopción de menores. } \\
\text { INEXEQUIBLE } \\
\text { C-193 }\end{array}$ & $\begin{array}{l}\text { En opinión del investigador el decreto contradice el artículo } 116 \text { de } \\
\text { la Constitución, pues constitucionalmente no se otorga la posibilidad } \\
\text { para que un órgano de control, como la Procuraduría General de } \\
\text { la Nación, asuma ciertas competencias jurisdiccionales. La Corte } \\
\text { Constitucional declaró la inexequibilidad de la totalidad del decreto, } \\
\text { por no superar los juicios de: i) motivación suficiente, ii) ausencia de } \\
\text { arbitrariedad, iii) incompatibilidad, iv) necesidad, v) proporcionalidad } \\
\text { y vi) arbitrariedad. Los magistrados Carlos Bernal y Alejandro Linares } \\
\text { salvaron su voto. (Corte Constitucional, C-193, 2020). }\end{array}$ \\
\hline
\end{tabular}

b. Con contadas excepciones, inter alia, el Procurador General de la Nación y de la Universidad Externado de Colombia quienes solicitaron la declaratoria de exequibilidad del decreto. Resulta interesante como este decreto suscitó el interés ciudadano con el alto número de intervenciones, esto sin duda contribuye a la deliberación en el marco de un proceso de constitucionalidad. 


\begin{tabular}{|c|c|c|c|}
\hline $\mathrm{N}^{\circ}$. & D.L. $^{\mathrm{a}}$ & $\begin{array}{l}\text { OBJETO - DECISIÓN } \\
\text { CORTE CONSTITUCIONAL }\end{array}$ & $\begin{array}{l}\text { RAZONES DE ABUSO NORMATIVO POR PARTE } \\
\text { DEL LEGISLADOR EXCEPCIONAL }\end{array}$ \\
\hline 21 & $\begin{array}{l}568 \mathrm{del} \\
15 / 04\end{array}$ & $\begin{array}{l}\text { Por el cual se crea el impuesto } \\
\text { solidario en razón a la emer- } \\
\text { gencia del COVID-19. } \\
\text { INEXEQUIBLE parcial } \\
\text { C-293 }\end{array}$ & $\begin{array}{l}\text { El mentado decreto creó un impuesto solidario por un término de } 3 \\
\text { meses para conjurar la crisis económica causada por la pandemia, que } \\
\text { tenía como sujeto pasivo al universo de funcionarios públicos, contra- } \\
\text { tistas del Estado y pensionados cuyo ingreso mensual fuese superior } \\
\text { a } 10 \text { millones de pesos. Excluyó algunos funcionarios como los traba- } \\
\text { jadores de la salud y las fuerzas militares y Policía Nacional. La medida } \\
\text { indicada fue muy cuestionada por diferentes sectores sociales, lo que } \\
\text { se refleja en el alto número de intervenciones ciudadanas durante el } \\
\text { trámite del control automático de constitucionalidad. Cerca de } 200 \\
\text { intervenciones se presentaron y el común denominador fue el de la } \\
\text { declaratoria de inexequibilidadb. La Corte Constitucional declaró la in- } \\
\text { constitucionalidad del impuesto, y sólo dejó a salvo lo relacionado con } \\
\text { el aporte voluntario. A su juicio, existen unos límites constitucionales } \\
\text { al poder impositivo extraordinario del Gobierno nacional durante los } \\
\text { estados de excepción. En concreto, no se superaron los siguientes jui- } \\
\text { cios: i) No contradicción específica (generalidad y equidad e igualdad } \\
\text { tributaria), impuesto directo que confundió el concepto de capacidad } \\
\text { tributaria con el ingreso, ii) No discriminación, iii) No acreditó pre- } \\
\text { supuesto de motivación suficiente, iv) Juicio de necesidad fáctica, v) } \\
\text { Juicio de no contradicción específica. Los magistrados Carlos Bernal, } \\
\text { Diana Fajardo y Luis Guillermo Guerrero salvaron su voto. Antonio } \\
\text { Lizarazo presentó salvamento de voto parcial (Corte Constitucional, } \\
\text { C-293, 2020). }\end{array}$ \\
\hline 22 & $\begin{array}{l}569 \mathrm{del} \\
15 / 04\end{array}$ & $\begin{array}{l}\text { Amplia el termino de opera- } \\
\text { ción del Centro de Logística y } \\
\text { transporte y adopta medidas } \\
\text { sobre el transporte de pasa- } \\
\text { jeros de carga y aéreo en el } \\
\text { marco de las restricciones } \\
\text { movilidad y del aislamiento. } \\
\text { EXEQUIBLE } \\
\text { C-239 }\end{array}$ & $\begin{array}{l}\text { El referido decreto no era requerido dentro de las facultades ex- } \\
\text { traordinarias del Gobierno Nacional, ya que es un asunto que podía } \\
\text { desarrollarse dentro de las competencias ordinarias de la Aeronáutica } \\
\text { Civil, como ente rector de la materia. El magistrado Alberto Rojas } \\
\text { presentó salvamento parcial de voto frente a la declaratoria de cons- } \\
\text { titucionalidad del decreto en cuestión (Corte Constitucional, C-293, } \\
\text { 2020). }\end{array}$ \\
\hline 23 & $\begin{array}{l}574 \text { del } \\
15 / 04\end{array}$ & $\begin{array}{l}\text { Medidas en materia de minas } \\
\text { y energía, en el marco del } \\
\text { Estado de excepción } \\
\text { EXEQUIBLE } \\
\text { C-241 }\end{array}$ & $\begin{array}{l}\text { Dicho decreto merece especial atención, pues es lamentable que ha- } \\
\text { ya sido declarado exequible en su totalidad sin el menor reparo frente } \\
\text { a diversas disposiciones que resultan inconstitucionales. Sin embargo, } \\
\text { se destacan los oportunos salvamentos parciales de voto de los ma- } \\
\text { gistrados i) Diana Fajardo, para quien el artículo } 9 \text { debió ser declarado } \\
\text { inconstitucional y el } 10 \text { que debió condicionarse en su interpretación; } \\
\text { ii) Gloria Ortiz, quien consideró que el artículo } 2 \text { debió declararse } \\
\text { exequible siempre y cuando se incluyera a la población más vulnera- } \\
\text { ble del sector minero: la minería artesanal; y, el artículo } 5 \text { que debió } \\
\text { ser declarado inexequible; iii) Cristina Pardo, para quien el parágrafo } \\
\text { del artículo } 4 \text { y el artículo } 10 \text { no supera el juicio de conexidad, pues } \\
\text { son medidas que nada tienen que ver con la declaratoria del Estado } \\
\text { de excepción; iv) Alberto Rojas, que consideró la inconstitucionalidad } \\
\text { del artículo 2, por no superar los juicios de no discriminación y pro- } \\
\text { porcionalidad, artículo } 9 \text { por ser inconexo y no contar con motivación } \\
\text { suficiente, necesidad y proporcionalidad por las vastas facultades al } \\
\text { Ministerio de Minas y Energía, y el artículo } 10 \text { que debió condicionar- } \\
\text { se frente a la vigencia de la medida. Es decir, únicamente mientras } \\
\text { dure el Estado de excepción (Corte Constitucional C-241, 2020). } \\
\text { Además de los argumentos expresados en los salvamentos parciales } \\
\text { de voto, es necesario llamar la atención sobre el hecho infortunado } \\
\text { de que la Corte Constitucional avale la disposición que concede una } \\
\text { facultad tan amplia al Ministerio de Minas y Energía para declarar la } \\
\text { emergencia eléctrica en el país (artículo 9). Dicha normativa no tiene } \\
\text { parangón ni antecedente en el ordenamiento jurídico. }\end{array}$ \\
\hline
\end{tabular}




\begin{tabular}{|c|c|c|c|}
\hline $\mathrm{N}^{\circ}$. & D.L. ${ }^{a}$ & $\begin{array}{l}\text { OBJETO - DECISIÓN } \\
\text { CORTE CONSTITUCIONAL }\end{array}$ & $\begin{array}{c}\text { RAZONES DE ABUSO NORMATIVO POR PARTE } \\
\text { DEL LEGISLADOR EXCEPCIONAL }\end{array}$ \\
\hline 24 & $\begin{array}{l}575 \text { del } \\
15 / 04\end{array}$ & $\begin{array}{l}\text { Se adoptan medidas en sector } \\
\text { infraestructura y transporte } \\
\text { para mitigar efectos negativos } \\
\text { a la economía. } \\
\text { EXEQUIBLE PARCIAL } \\
\text { C-294 }\end{array}$ & $\begin{array}{l}\text { Artículos } 9 \text { y } 10 \text { inexequibles. El primero porque el cambio del sistema } \\
\text { de avalúo de predios requeridos para los proyectos de infraestructura } \\
\text { no satisface el juicio de conexidad externa frente a los hechos que } \\
\text { motivaron la declaratoria de la crisis. El segundo está relacionado con } \\
\text { una causal que se agregó a los actos contrarios a la libre competencia } \\
\text { sobre el incumplimiento de un pago de obligación dineraria por un } \\
\text { contratista de infraestructura de transporte, por falta de conexidad } \\
\text { externa con el Estado de excepción. El magistrado Carlos Bernal salvó } \\
\text { su voto. (Corte Constitucional C-294, 2020). }\end{array}$ \\
\hline 25 & $\begin{array}{l}580 \text { del } \\
15 / 04\end{array}$ & $\begin{array}{l}\text { Se dictan medidas en temas } \\
\text { de servicios públicos } \\
\text { INEXEQUIBLE } \\
\text { C-256 }\end{array}$ & $\begin{array}{l}\text { El decreto consignaba medidas fundamentales para aliviar la carga } \\
\text { del pago de servicios públicos de los estratos } 1,2 \text { y } 3 \text { fue declarado } \\
\text { inexequible por un vicio de forma en que incurrió el Gobierno (Corte } \\
\text { Constitucional, C-256, 2020). El decreto debía ser firmado por el } \\
\text { presidente y todos los ministros. Sin embargo, faltaron las firmas de } \\
\text { los ministros de Salud y Protección Social y de la ministra de Ciencia, } \\
\text { Tecnología e Innovación. }\end{array}$ \\
\hline 26 & $\begin{array}{l}637 \text { del } \\
06 / 05\end{array}$ & $\begin{array}{l}\text { Por el cual se declara un } \\
\text { Estado de emergencia } \\
\text { Económica, Social y Ecológica. } \\
\text { EXEQUIBLE } \\
\text { C-326 }\end{array}$ & $\begin{array}{l}\text { Este es el segundo decreto que declara el Estado de excepción. } \\
\text { Aunque el decreto fue declarado exequible en su totalidad, hubo dos } \\
\text { aclaraciones de voto en las que se hicieron precisiones importantes. } \\
\text { Por un lado, el magistrado José Fernando Reyes consideró que la } \\
\text { Corte debió ejercer un control más riguroso que el planteado sobre } \\
\text { el decreto que declaró el primer estado de excepción. A su juicio, las } \\
\text { circunstancias urgentes ya no son sorpresivas, y, por tanto, no puede } \\
\text { extenderse la competencia legislativa al Gobierno Nacional. Además, } \\
\text { debe tenerse en cuenta que el Congreso ya se encuentra sesionando } \\
\text { de manera virtual, por lo que ya no existe un vacío legislativo. Y, por } \\
\text { el otro, el magistrado Alberto Rojas consideró que la Corte ha omitido } \\
\text { la tarea de realizar el control de constitucionalidad a los decretos que } \\
\text { ordenaron el aislamiento preventivo obligatorio (Corte Constitucional } \\
\text { C-326, 2020). Estos decretos, a pesar de ser los más restrictivos en } \\
\text { relación con los derechos fundamentales, no fueron materia de con- } \\
\text { trol por el tribunal constitucional. }\end{array}$ \\
\hline 27 & $\begin{array}{l}659 \text { del } \\
13 / 05\end{array}$ & $\begin{array}{l}\text { Autoriza la entrega de una } \\
\text { transferencia monetaria no } \\
\text { condicionada, adicional y } \\
\text { extraordinaria en favor de los } \\
\text { beneficiarios de los programas } \\
\text { Familias en Acción, Protección } \\
\text { Social al Adulto Mayor- } \\
\text { Colombia Mayor y Jóvenes en } \\
\text { Acción. } \\
\text { No se ha proferido sentencia }\end{array}$ & $\begin{array}{l}\text { Sobre este decreto aún no se ha dictado la sentencia correspondiente } \\
\text { por parte de la Corte Constitucional. Sin embargo, se quiere desta- } \\
\text { car la intervención de Dejusticia y la Universidad Nacional, quienes } \\
\text { consideran que el referido decreto, a pesar de buscar una finalidad } \\
\text { loable que es conexa a la crisis económica generada por la pandemia, } \\
\text { debe condicionarse para que la medida adoptada sea suficiente para } \\
\text { lograr los cometidos propuestos. En otras palabras, el decreto sólo } \\
\text { será constitucional si la transferencia asignada garantiza los gastos de: } \\
\text { alimentación adecuada, vivienda digna y acceso a servicios públicos } \\
\text { domiciliarios. } \\
\text { En este orden de ideas, la medida es insuficiente porque el monto } \\
\text { asignado no alcanza a representar el valor señalado como umbral de } \\
\text { pobreza (2018: } \$ 257.433 \text { ). De acuerdo con la Resolución } 928 \text { de } 2020 \\
\text { del Departamento para la Prosperidad Social, reglamentaria del de- } \\
\text { creto legislativo, la suma asignada es por valor de } \$ 145.000 \text { mensual, } \\
\text { la cual debe sumarse con el monto otorgado en los diferentes progra- } \\
\text { mas: i) Familias en Acción: cuyo monto máximo (familia con un menor } \\
\text { de } 6 \text { años) es de } \$ 160.000, \text { ii) Adulto Mayor: } \$ 80.000 \text { y Jóvenes en } \\
\text { Acción: } \$ 184.000 \text { (con destino a gastos de educación). En consecuen- } \\
\text { cia, sumados estos valores con la transferencia a que se refiere el } \\
\text { Decreto Legislativo } 659 \text {, no se alcanza a superar el umbral de pobreza. }\end{array}$ \\
\hline
\end{tabular}




\begin{tabular}{|c|c|c|c|}
\hline $\mathrm{N}^{\circ}$. & D.L. ${ }^{a}$ & $\begin{array}{l}\text { OBJETO - DECISIÓN } \\
\text { CORTE CONSTITUCIONAL }\end{array}$ & $\begin{array}{c}\text { RAZONES DE ABUSO NORMATIVO POR PARTE } \\
\text { DEL LEGISLADOR EXCEPCIONAL }\end{array}$ \\
\hline 28 & $\begin{array}{l}774 \text { del } \\
03 / 06\end{array}$ & $\begin{array}{l}\text { Adiciona el Presupuesto } \\
\text { General de la Nación de la } \\
\text { vigencia fiscal de } 2020 \text { y se } \\
\text { efectúa su correspondiente } \\
\text { liquidación. } \\
\text { EXEQUIBLE PARCIAL } \\
\text { C-351 }\end{array}$ & $\begin{array}{l}\text { La Corte mantuvo su posición jurisprudencial de declarar inexequibles } \\
\text { los artículos } 3,4 \text { y } 5 \text { que se refieren a la liquidación del presupuesto. } \\
\text { La liquidación se puede hacer con las normas de carácter ordinario, } \\
\text { sin que se retire de la intervención del legislador excepcional. Los } \\
\text { magistrados Luis Guillermo Guerrero y Antonio Lizarazo salvaron } \\
\text { parcialmente su voto frente a la declaratoria de inconstitucionalidad } \\
\text { (Corte Constitucional, C-351, 2020). }\end{array}$ \\
\hline 29 & $\begin{array}{l}770 \text { del } \\
03 / 06\end{array}$ & $\begin{array}{l}\text { Crea y determina las condicio- } \\
\text { nes de acceso del Programa } \\
\text { de Apoyo para el Pago de la } \\
\text { Prima de Servicios - PAP. } \\
\text { EXEQUIBLE } \\
\text { C-324 }\end{array}$ & $\begin{array}{l}\text { Quizás, este sea el decreto que contiene mayor número de medidas } \\
\text { por la extensión de su articulado. } 30 \text { artículos distribuidos en } 5 \text { ca- } \\
\text { pítulos. El capítulo I establece la medida de protección al cesante, el } \\
\text { capítulo II Medidas alternativas respecto a la Jornada de Trabajo, el } \\
\text { capítulo III alternativas para el primer pago de la prima de servicios, el } \\
\text { capítulo IV programa de apoyo para el pago de la prima de servicios- } \\
\text { PAP, y el capítulo V programa de auxilio a los trabajadores en suspen- } \\
\text { sión contractual. Como se ve, todas son medidas laborales que regu- } \\
\text { lan diferentes contenidos. Sin duda, algunas de ellas son necesarias. } \\
\text { No obstante, como es un paquete tan amplio de medidas laborales, } \\
\text { fácilmente se puede desconocer la prohibición de desmejora de los } \\
\text { derechos de los trabajadores contenida en el artículo } 215 \text { constitu- } \\
\text { cional y en el } 50 \text { de la Ley Estatutaria de los estados de excepción. Así } \\
\text { lo plasmó la magistrada Cristina Pardo en su salvamento de voto, en } \\
\text { relación con los artículos } 2 \text { y } 3 \text {, pues implican una modificación a la } \\
\text { normativa ordinaria para excluir del programa de protección al cesan- } \\
\text { te a los afiliados a las cajas de compensación familiar categorías C y } \\
\text { D, y, además, redujo el término del beneficio de } 6 \text { a } 3 \text { meses. De igual } \\
\text { manera, el inciso primero del artículo } 6 \text { debió condicionarse porque } \\
\text { otorga la posibilidad de llegar a acuerdos sobre el pago diferido de la } \\
\text { prima, incluso a los empleadores que no resultaron afectados eco- } \\
\text { nómicamente por la pandemia. El magistrado Alberto Rojas también } \\
\text { señaló que la Corte no debió flexibilizar la interpretación de los artí- } \\
\text { culos } 215 \text { y } 50 \text { de la LEEE, respecto a la desmejora de derechos sala- } \\
\text { riales, pues en los artículos } 2,3,4,5,6 \text { y } 20 \text { se evidencia una fuerte } \\
\text { merma de estos derechos de los trabajadores. La decisión mayoritaria } \\
\text { de la Corte fue la de declarar la exequibilidad total del decreto, salvo } \\
\text { el parágrafo } 1 \text { del artículo } 5 \text { y una expresión contenida en los artículos } \\
10, \text { párrafo } 3 \text { y artículo } 22 \text {, en los cuales se condicionó la exequibili- } \\
\text { dad (Corte Constitucional, C-324, } 2020 \text { ). }\end{array}$ \\
\hline 30 & $\begin{array}{l}797 \mathrm{del} \\
04 / 06\end{array}$ & $\begin{array}{l}\text { Medidas transitorias en ma- } \\
\text { teria de arrendamiento de } \\
\text { locales } \\
\text { Comerciales. } \\
\text { Aún no se ha publicado la } \\
\text { sentencia }\end{array}$ & $\begin{array}{l}\text { La Corte declaró la inexequibilidad del decreto, toda vez que afecta la } \\
\text { autonomía de la voluntad privada y la libertad contractual, tratándose } \\
\text { de comerciantes. El alto tribunal señaló que el decreto no era necesa- } \\
\text { rio en el marco del Estado de Emergencia y estimó que el Código Civil } \\
\text { y el Código de Comercio tenían diversos instrumentos para superar } \\
\text { circunstancias imprevisibles en el desarrollo de la voluntad contrac- } \\
\text { tual. (El Espectador, 2020). }\end{array}$ \\
\hline 31 & $\begin{array}{l}802 \text { del } \\
04 / 06\end{array}$ & $\begin{array}{l}\text { Modificación al Dto. } 558 \text { de } \\
15 \text { de abril } \\
\text { INEXEQUIBLE } \\
\text { C-308 }\end{array}$ & $\begin{array}{l}\text { El decreto fue declarado inconstitucional en su totalidad. No se sa- } \\
\text { tisfacen los juicios de conexidad, necesidad ni motivación suficiente. } \\
\text { Básicamente, la descapitalización del régimen pensional de Ahorro } \\
\text { Individual no guarda relación directa con los efectos económicos de- } \\
\text { rivados de la COVID-19, sino que obedecen a un problema estructural } \\
\text { del que fueron advertidos desde el surgimiento de dicho régimen } \\
\text { privado. De igual manera, el Gobierno Nacional no logró demostrar } \\
\text { la insuficiencia de la legislación ordinaria para afrontar la crisis del } \\
\text { sistema pensional., la Corte consideró que el problema estructural del } \\
\text { régimen pensional de carácter privado requiere de la mayor delibera- } \\
\text { ción democrática en el Congreso, aspecto que no se satisface por el } \\
\text { legislador excepcional (Corte Constitucional. C-308, 2020). }\end{array}$ \\
\hline
\end{tabular}




\begin{tabular}{|c|c|c|c|}
\hline $\mathrm{N}^{\circ}$. & D.L. ${ }^{a}$ & $\begin{array}{l}\text { OBJETO - DECISIÓN } \\
\text { CORTE CONSTITUCIONAL }\end{array}$ & $\begin{array}{l}\text { RAZONES DE ABUSO NORMATIVO POR PARTE } \\
\text { DEL LEGISLADOR EXCEPCIONAL }\end{array}$ \\
\hline 32 & $\begin{array}{l}805 \\
\text { del } \\
04 / 06\end{array}$ & $\begin{array}{l}\text { Apoyo económico para todas } \\
\text { las Notarías del país, por el } \\
\text { término de cuatro (4) meses, } \\
\text { con cargo a los recursos del } \\
\text { Fondo Cuenta Especial del } \\
\text { Notariado } \\
\text { No se ha proferido sentencia }\end{array}$ & $\begin{array}{l}\text { Ala fecha de elaboración de la presente investigación no se ha pro- } \\
\text { ferido la respectiva sentencia. Sin embargo, el autor sostiene que la } \\
\text { motivación del Gobierno Nacional para priorizar en el grupo de traba- } \\
\text { jadores en cuestión es insuficiente. En primer lugar, en la parte motiva } \\
\text { del decreto se muestran las cifras de la afectación económica en los } \\
\text { diferentes sectores sin que se ofrezca un panorama sobre dicha mer- } \\
\text { ma o disminución en las notarías del país. La conclusión es bastante } \\
\text { especulativa, pues a raíz de la grave afectación en diferentes sectores } \\
\text { económicos se justificó la necesidad de apoyar a los trabajadores de } \\
\text { las notarías. En segundo lugar, el apoyo que incluye a la totalidad de } \\
\text { notarías del país es bastante amplio. Dentro de los requisitos exigidos } \\
\text { por el artículo } 3 \text { no se incluyó el de la demostración de la disminución } \\
\text { de ingresos, por lo menos de manera sumaria. Es un beneficio bastan- } \\
\text { te amplio que carece de un soporte o estudio mínimo que avale esa } \\
\text { necesidad de incluir a todas las notarías nacionales. Además, debe te- } \\
\text { nerse en cuenta que los notarios de las ciudades más importantes del } \\
\text { país pueden percibir un ingreso mensual que está } 10 \text { o hasta } 15 \text { veces } \\
\text { por encima del que perciben los altos cargos públicos en Colombia, } \\
\text { como presidente de la república, congresistas y magistrados de altas } \\
\text { cortes. En consecuencia, las notarías bien podrían superar la contin- } \\
\text { gencia y asegurar el salario de sus empleados, sin perjuicio de una } \\
\text { disminución de ingresos para el notario público. Es diferente si el apo- } \\
\text { yo se dirigiera exclusivamente para las notarías con menores ingresos } \\
\text { que están en los círculos más pequeños y de menores recursos. En } \\
\text { últimas, pareciera que con el referido decreto se privilegió un grupo } \\
\text { que tiene la posibilidad de realizar presión y lobby ante el Gobierno, } \\
\text { por la misma condición de quienes ostentan el cargo de notario públi- } \\
\text { co, pero no por la inminencia de rescatar o aliviar un sector que haya } \\
\text { sido golpeado por la crisis de la pandemia. }\end{array}$ \\
\hline 33 & $\begin{array}{l}811 \text { del } \\
04 / 06\end{array}$ & $\begin{array}{l}\text { Medidas relacionadas con la } \\
\text { inversión y la enajenación de } \\
\text { la participación accionaría del } \\
\text { Estado. }\end{array}$ & $\begin{array}{l}\text { El decreto } 811 \text { es una clara manifestación de privatización de los } \\
\text { activos nacionales. Por un lado, los artículos } 7 \text { y } 8 \text { señalan un procedi- } \\
\text { miento ágil bajo el cual se permita la venta de los activos estratégicos } \\
\text { nacionales. De entrada, las disposiciones son contrarias al ordena- } \\
\text { miento constitucional, en particular a los artículos } 60 \text {, "democrati- } \\
\text { zación de la titularidad de la participación estatal en las empresas", } \\
\text { y el artículo } 150-9 \text { que exige la autorización del Congreso para que } \\
\text { el Gobierno pueda enajenar bienes nacionales. Y, por el otro, la Ley } \\
226 \text { de } 1995 \text { ya establecía un procedimiento para enajenación de la } \\
\text { propiedad accionaria estatal. De tal modo que no se supera el juicio } \\
\text { de necesidad jurídica, y tampoco el de conexidad con la declaratoria } \\
\text { del Estado de excepción, pues la determinación de un procedimiento } \\
\text { fast track para venta de la participación accionaria no implica una } \\
\text { respuesta idónea para la atención de la crisis sanitaria causada por el } \\
\text { Coronavirus. En los medios de comunicación se anunció que la Corte } \\
\text { declaró la inexequibilidad de este decreto. }\end{array}$ \\
\hline 34 & \begin{tabular}{|l}
813 del \\
$04 / 06$
\end{tabular} & $\begin{array}{l}\text { Modifica el Presupuesto } \\
\text { General de la Nación de la } \\
\text { vigencia fiscal de } 2020 \text { y se } \\
\text { efectúa su correspondiente } \\
\text { liquidación. }\end{array}$ & $\begin{array}{l}\text { La Corte declaró la inexequibilidad de los artículos } 6,7,8,9,10,11 \\
\text { y } 12 \text { que se refieren a la liquidación del presupuesto, y moduló sus } \\
\text { efectos de manera retroactiva, esto es, a partir de la expedición del } \\
\text { decreto. El alto tribunal mantuvo su precedente frente a los diferen- } \\
\text { tes decretos expedidos en el marco del Estado de excepción y que se } \\
\text { refieren a materias presupuestarias. En todos los casos se ha declara- } \\
\text { do la inexequibilidad de los artículos que versan sobre la liquidación. } \\
\text { Los magistrados Antonio Lizarazo y Luis Moreno(E) salvaron su voto } \\
\text { respecto a la declaratoria de inconstitucionalidad. }\end{array}$ \\
\hline
\end{tabular}

Fuente: Elaboración propia 
47. Como se observa, es posible concluir que hay un abuso de las facultades excepcionales del Ejecutivo, porque los decretos expedidos se enmarcan dentro de alguno de los siguientes supuestos: i) las medidas habían podido ser adoptadas con fundamento en el ordenamiento ordinario, ii) las medidas no guardan conexidad alguna con los hechos que sirvieron de fundamento para declarar la crisis, o iii) las medidas adoptadas son abiertamente inconstitucionales.

48. En el primer grupo se encuentran las medidas sobre suspensión de desembarque, prevención, diagnóstico y tratamiento de la COVID-19, servicio público de transporte e infraestructura, fortalecimiento del Fondo Nacional de Garantías, acceso de hogares más vulnerables a productos básicos, liquidación del Presupuesto General de la Nación, creación de una subcuenta para la gestión del riesgo, operación del Centro de Logística y transporte (filas 1, 4-7, 10-13, $19,22,28$ y 34 ). Si bien un buen número de las medidas eran necesarias para conjurar la crisis declarada, no se requería de la expedición de decretos legislativos, toda vez que el Gobierno pudo haber hecho uso de las facultades ordinarias que ya se encontraban previstas en el ordenamiento jurídico. Debe advertirse que con ocasión de los estados de excepción resulta vital adoptar medidas que ayuden a conjurar la crisis. Sin embargo, lo anterior no quiere decir que todas las medidas deban ser de carácter extraordinario, pues el mismo ordenamiento prevé facultades a las que pueden acudirse sin que implique la necesidad de expedir normativa de tipo extraordinario. En suma, se reprocha esa intención del ejecutivo de inflar el ordenamiento jurídico.

49. En el segundo grupo se encuentran las medidas que versan sobre las siguientes materias: financiamiento de proyectos de inversiones públicas con recursos del Fondo de Regalías, sector infraestructura y transporte, descapitalización del régimen pensional y apoyo económico para las notarías (filas 9, 24, 31-32). Las medidas mencionadas no guardan relación con los hechos que sirvieron de fundamento para declarar el Estado de emergencia. Por ejemplo, no se comprende la razón por la cual se decide brindar un apoyo económico a las notarías del país, o cómo el financiamiento de proyectos de inversiones públicas con recursos de regalías pueda ayudar a conjurar la situación de crisis declarada. Estas son acciones que no ayudan o alivian las graves consecuencias causadas por la pandemia. En conclusión, el Gobierno no estaba facultado para dictar normas con fuerza material de ley sobre estos asuntos.

50. En el tercer grupo se expidieron medidas que versan sobre las siguientes materias: creación del fondo de mitigación de emergencias, autorización a gobernadores y alcaldes para reorientación de rentas, reducción de tarifas de impuestos y realización de movimientos presupuestales, contratación estatal, préstamos del Fondo de Riesgos Laborales para el FOME, porcentajes de programación nacional, Sistema General de Pensiones, funciones de adopción de menores a procuradores judiciales, impuesto solidario, minas y energía, transferencia monetaria, arrendamiento de locales comerciales y enajenación de participación accionaria estatal (filas: 2, 3, 8, 14-15, 16, 18, 20, 27, 30 y 33). Como se señaló, estos decretos legislativos contravienen disposiciones constitucionales, razón por la cual, el legislador excepcional no tiene facultades para expedir normas que sean contrarias a la Constitución.

51. Sumado a lo anterior, es necesario llamar la atención sobre tres aspectos. En primer lugar, el Decreto 580 (fila 25), que si bien consignaba una medida sobre subsidios a los servicios públicos, la cual resulta indispensable para la población más vulnerable ${ }^{21}$, fue declarado inexequible por vicios de forma. En el caso indicado, por no contar con la firma de todos los ministros del Gobierno Nacional. Cabe resaltar que este fue el único decreto en el que el Gobierno Nacional no incluyó todas

21. Según el artículo primero de este decreto, los subsidios de acueducto, alcantarillado y aseo serían asignados hasta 31 de diciembre de 2020 hasta un máximo del $80 \%$ para el estrato $1,50 \%$ para el estrato 2 y $40 \%$ para el estrato 3 . 
las firmas de los ministros. En segundo lugar, sobre el Decreto 637 que ordenó el segundo estado de excepción, vale la pena preguntarse si era absolutamente necesario ordenar un nuevo estado de emergencia, pues la inminencia y urgencia ya se habían mencionado en la primera declaratoria. El Decreto 637 se expide casi dos meses después de haberse decidido declarar el Estado de excepción por los graves efectos de la COVID-19, lo que implica que estos hechos ya no resultaban sorpresivos en el contexto nacional. El Gobierno pudo explorar otros mecanismos que no cercenaran el principio de deliberación política. Por ejemplo, pudo optar por mensaje de urgencia que reduce de manera considerable los tiempos que tarda un proyecto de ley en el Congreso de la República. Lo anterior sólo refleja el débil papel del legislativo durante la grave crisis generada por la pandemia, convertido en un convidado de piedra.

52. En tercer lugar, es materia de preocupación el hecho de que en Colombia no se haya realizado el control automático de constitucionalidad frente a los decretos que más tensión generaban con la posible afectación de derechos y libertades individuales. Por ejemplo, los decretos que ordenaron el aislamiento preventivo obligatorio, y que de manera consecutiva mantuvieron a la ciudadanía colombiana en cuarentenas desde el 22 de marzo y hasta el 31 de agosto de 2020. Sin duda, Colombia encabeza la lista de países con cuarentena de mayor duración. La referida normativa no se expidió bajo la forma de "decretos legislativos", sino que se hizo mediante las facultades ordinarias del presidente de la república. Un grupo de juristas de Dejusticia solicitaron a la Corte Constitucional que asumiera de oficio el control de constitucionalidad frente a estos decretos apelando al concepto material, es decir, que a pesar de que las medidas se adoptaran en decretos ordinarios, materialmente se trataba de una ley, pues limitaba el ejercicio de algunos derechos fundamentales (Dejusticia, 2020).

53. La tesis supra no fue acogida por la Corte Constitucional, y ni siquiera suscitó pronunciamiento alguno. Únicamente el magistrado Alberto Rojas dejó consignado este aspecto en sus salvamentos de voto a las sentencias que declararon la exequibilidad de los decretos 417 y 637, que declararon el Estado de excepción. y a pesar de que dichos decretos pudieran ser revisados por el Consejo de Estado mediante los medios de control de carácter ordinario, Palacios es partidario de la tesis propuesta (Palacios, 2020), el suscrito está convencido del gran desacierto que cometió la Corte al no asumir la competencia bajo el proceso de control automático de constitucionalidad. Sin duda alguna, mantener cuarentenas prolongadas puede traspasar el lindero de la limitación y ubicarse en terrenos de la "suspensión" de algunos derechos fundamentales. A juicio del investigador, es una discusión de gran relevancia constitucional que por su aspecto material debió conocer el Tribunal Constitucional.

54. Ahora bien, la Corte Constitucional ha tenido un débil papel frente a su labor de juez controlador de la actividad legislativa del Ejecutivo Nacional. De los 115 decretos legislativos, el tribunal ha proferido cerca de 90 sentencias en las que tan solo en 6 casos se ha declarado la inexequibilidad total del decreto. Además, resulta importante que en 16 casos se ha proferido una decisión mixta, es decir, algunas disposiciones se declaran inexequibles y otras exequibles. Sin embargo, cabe resaltar los esfuerzos de los magistrados Alberto Rojas, Cristina Pardo y Diana Fajardo, quienes en sus salvamentos de voto presentaron argumentos razonables y suficientes para declarar la inconstitucionalidad de varias de las medidas ordenadas por el Gobierno Nacional. También se puede apreciar la corriente contraria, es decir, la de la defensa de la exequibilidad de los decretos legislativos, por parte de los magistrados Carlos Bernal, Luis Guillermo Guerrero y Antonio Lizarazo. Se observa que dicha corriente defendió de manera consistente las facultades del legislador de excepción, pues, incluso, en aquellas sentencias en que la decisión mayoritaria era la de declarar inexequible total o parcialmente un decreto, había un salvamento por parte de este grupo 
de magistrados. De los tres, Carlos Bernal fue quien más salvamentos de voto presentó frente a las declaratorias de inexequibilidad parcial que se hicieron en un buen número de decretos legislativos.

\section{CONCLUSIONES}

55. Desde el 2015 se eliminó la reelección presidencial en Colombia. Sin embargo, con tan solo la mitad del período constitucional, el presidente Duque ha logrado que nuestro país se sumerja en una ola de desbalance institucional. Su gobierno tiene plenos poderes en todas las ramas. Expidió 115 decretos con fuerza material de ley en tan solo 60 días, cuenta con mayorías en el Congreso que le permiten aprobar su agenda legislativa, $\mathrm{y}$ ha cooptado los principales órganos de control con sus principales allegados. Incluso, cooptó la Fiscalía General de la Nación. Por el contrario, el legislativo pasa por uno de sus peores momentos. Se encuentra muy debilitado. De esta manera, la Corte Constitucional, que podría nivelar el desbalance y evitar el monopolio de la ley en cabeza del Ejecutivo, desempeña un papel bastante tímido. El juez prudente o minimalista no puede ser el modelo a seguir por el alto tribunal en un Estado de excepción. El Estado social de derecho está siendo defendido por una minoría de magistrados quienes a través de los "salvamentos de voto" consignan los graves desaciertos de la jurisprudencia constitucional.

56. La defensa a ultranza que hace el Gobierno de la clase dominante se puede apreciar en las decisiones que en materia económica se han tomado para mitigar los efectos dejados por la pandemia. Poner dinero al servicio de la banca o gravar exclusivamente a los trabajadores del sector público con determinado salario evidencia una posición política de protección al sector financiero y los grandes capitales, en contraste con el menosprecio por la clase media trabajadora de nuestro país. Ramírez ofrece unas claves para entender el neofascismo del siglo XXI. Se comparte el interrogante que plantea el autor: “cómo puede un régimen de propensión democrática conservar la credibilidad popular que debería alimentarlo cuando, en su nombre se inclina tan nítidamente la balanza de poder hacia el 1 por 100 de la población?" (Ramírez, 2019). Colombia reúne algunas de las características de aquellos modelos que mutilan el Estado de derecho y se inclinan más por un autoritarismo libertario.

57. Por último, la COVID-19 en Colombia está ampliando aún más la brecha de desigualdad en uno de los países más desiguales del mundo. Sin embargo, la profunda desigualdad social no es un asunto que se encuentre en la agenda del actual gobierno. Así como lo plantea Ferrajoli, se considera que el principio dinámico de igualdad jamás será realizado plenamente, pues por naturaleza es imperfectamente realizable (Ferrajoli, 2019). Más aún, se censura el hecho de que aquellas desigualdades económicas y materiales, que la COVID-19 está incrementando, y limitan el ejercicio de los derechos no sean combatidas por el Gobierno colombiano. Se tiene absoluto convencimiento de que la constitucionalización del principio de igualdad material en el ordenamiento colombiano implica la obligación de que las autoridades actúen y propendan por la reducción de la desigualdad.

\section{REFERENCIAS BIBLIOGRÁFICAS}

» Andes, M. U. (2020). El patrón socioeconómico del Covid. El caso de Bogotá. Nota Macroeconómica, (23), 1-5.

» Banrep.(22 de septiembre de 2020). Banco de la República. Obtenido de https:// totoro.banrep.gov.co/analytics/saw.dll?Go\&Path=\%2Fshared $\% 2$ FSeries $\% 20$ Estad\%C3\%ADsticas_T\%2F1.\%20Reservas\%20internacionales\%2F1.1\%20

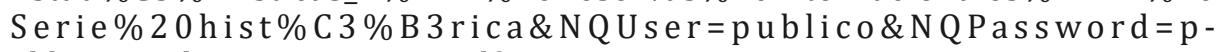
ublico123\&lang=es\&Options $=$ rdf 
» Barrera, P. (2020). COVID-19 en Colombia. Una oportunidad para el posicionamiento de los derechos sociales, económicos y culturales. En Altavilla, C. y Villegas, C. (Dirs.), Los desafíos del Derecho frente a la Pandemia COVID-19. Mirada del Derecho Argentino con aportes del Derecho Comparado(pp.221-228). Buenos Aires: Universidad Siglo 21 - IJ Editores

» Bermúdez, A. y. (2020). La cara étnica de la pandemia en Colombia. Nota Macroeconómica, 1-8. Obtenido de file://C:/Users/USUARIO/Desktop/ C\%C3\%A1tedras\%202020/Crisis\%20del\%20 constitucionalismo/Nota\%20 macroecon\%C3\%B3mica\%2024.\%20La\%20cara\%20\%C3\%A9tnica $\% 20$ de $\% 20$ la\%20pandemia\%20en\%20Col.pdf

» CIDH. (16 de septiembre de 2020). OEA. Obtenido de www.oas.org/es/cidh/ prensa/comunicados/2020/219.asp

» Congreso de la República de Colombia. (1994) Ley 137 de 1994.

»---. (2011). Ley 1474 de 2011.

$» \quad---$. (2018). Ley 1909 de 2018.

Consejo de Estado. (2 de julio de 2020). 2020-00183-01

Consejo de Estado. (18 de junio de 2020). 2020-00067-01

Constitución Política de la República de Colombia. (1991).

» Corte Constitucional. (31 de julio de 2008). Sentencia T-760. [M.P. Manuel José Cepeda Espinosa].

----. (14 de enero de 2019). Sentencia T-002 [Cristina Pardo Schlesinger].

----. (17 de mayo de 2019). Sentencia T-209. [M.P. Carlos Bernal Pulido].

---. (28 de mayo de 2020). Sentencia C-155. [M.P. Cristina Pardo Schlesinger].

---. (24 de julio de 2020). Sentencia C-194. [M.P. Carlos Bernal Pulido].

----. (8 de julio de 2020). Sentencia C-241. [M.P. Carlos Bernal Pulido].

----. (5 de agosto de 2020). Sentencia C-294. [M.P. Alejandro Linares Cantillo].

---. (19 de agosto de 2020). Sentencia C-326. [M.P. Richard S. Ramírez Grisales].

---. (3 de junio de 2020). Sentencia C-157. [M.P. Diana Fajardo Rivera].

----. (4 de junio de 2020). Sentencia C-162. [M.P. Alejandro Linares Cantillo].

---. (10 de junio de 2020). Sentencia C-169. [M.P. Antonio José Lizarazo Ocampo].

---. (10 de junio de 2020). Sentencia C-170. [M.P. Gloria Stella Ortiz Delgado].

---. (17 de junio 2020). Sentencia C-178. [M.P. Antonio Jose Lizarazo Ocampo].

---- (17 de junio de 2020). Sentencia C-181. [M.P. Alejandro Linares Cantillo].

----. (01de julio de 2020). Sentencia C-212. [M.P. Carlos Bernal Pulido].

----. (02 de julio de 2020). Sentencia C-215. [M.P. Luis Guillermo Guerrero Perez].

---. (13 de junio 2020). Sentencia C-185. [M.P. Alberto rojas Ríos].

----. (17 de junio de 2020). Sentencia C-186. [M.P. Antonio José Lizarazo Ocampo].

---. (24 de junio de 2020). Sentencia C-193. [Gloria Stella Ortiz Delgado]. 
》 rez].

»---.(23 de julio de 2020). Sentencia C-258. [M.P. Alejandro Linares Cantillo].

»---. (5 de agosto de 2020). Sentencia C-293. [M.P. Gloria Stella Ortiz Delgado, Cristina Pardo Schlesinger].

»---. (12 de agosto de 2020). Sentencia C-308. [M.P. Alejandro Linares Cantillo].

$»$---. (19 de agosto de 2020). Sentencia C-324. [M.P. Antonio Jose Lizarazo Ocampo].

» ----. (26 de agosto 2020). Sentencia C-351. [M.P. Richard S. Ramírez Grisales].

»---.(29 de enero de 2020). Sentencia T-030. [M.P. Diana Fajardo Rivera].

» DANE. (2019). Población indígena en Colombia. Bogotá: DANE.

»---. (2019a). Población negra, afrocolombiana, raizal y palenquera. Bogotá: DANE.

» ----. (2020). Déficit habitacional. Bogotá: DANE.

$» \quad----$. (31 de agosto de 2020). Principales indicadores del mercado laboral. Recuperado 6 de septiembre de 2020 de https://n9.cl/0rjx

» Defensoría. (2019). La tutela y los derechos a la salud y a la seguridad social 2018. Bogotá: Defensoría del Pueblo.

» Dejusticia. (30 de junio de 2020). Dejusticia. Recuperado 6 de septiembre de 2020 de: https://n9.cl/xbt52

» El Espectador. (18 de agosto de 2020). Duque acepta renuncia de minjusticia Margarita Cabello. Recuperado 12 de septiembre de 2020 de: https://n9.cl/tx94v

» ----. (01 de septiembre de 2020). Carlos Camargo se posesionó como defensor del Pueblo. Recuperado 21 de septiembre de 2020 de: https://n9.cl/ykb0

»----. (17 de septiembre de 2020). Corte Constitucional tumba decreto sobre arrendamientos comerciales en la pandemia. Recuperado 2 de octubre de 2020 de: https://n9.cl/tx94v

» El Tiempo. (20 de agosto de 2018). Con 203 votos, Felipe Córdoba fue elegido como Contralor General. Recuperado 20 de septiembre de 2020 de: https:// n9.cl/6k1r

»El Tiempo. (27 de agosto de 2020). Margarita Cabello, elegida nueva procuradora general de la nación. Recuperado 21 de septiembre de 2020 de: https://n9.cl/ ykb0

» Ferrajoli, L. (2019). Manifiesto por la igualdad. Madrid: Trotta.

» Fiscalía General de la Nación . (04 de septiembre de 2020). Obtenido de https:// www.fiscalia.gov.co/colombia/la-entidad/el-fiscal/ 
Gañán, J. (2010). Los muertos de la Ley 100. Bogotá: Externado .

» Ligarreto, R. 2. (20 de mayo de 2020). Universidad Javeriana. Pesquisa. Obtenido de Educación virtual: realidad o ficción en tiempos de pandemia: https://www. javeriana.edu.co/pesquisa/educacion-virtual-realidad-o-ficcion-en-tiempos-depandemia/

» MinSalud. (02 de Septiembre de 2020). Covid19. Recuperado el 3 de octubre de 2020 de: https://covid19.minsalud.gov.co/

» Murillo, D. (20 de abril de 2020). DEJUSTICIA. Grupos étnicos en la pandemia: sin agua para comer o para lavarse las manos. Recuperado el 5 de junio de 2020 de: https://n9.cl/w3h6

» Palacios, A. (30 de Junio de 2020). Sin cuarentena en el control abstracto de constitucionalidad. Revista Derecho de Estado. Recuperado el 2 de agosto de 2020 de: https://n9.cl/a3eh3

» Potafolio. (20 de agosto de 2018). Carlos Felipe Córdoba es el nuevo Contralor General de la República. Portafolio. Recuperado el 25 de agosto de 2020 de: https://n9.cl/aamov

» Ramírez, F. (2019). La pendiente neoliberal: ¿Neo-fascismo, postfacismo, autoritarismo libertario? En A. y. Guamán, Neofascismo. La bestia neoliberal (págs. 19-38). Madrid: Siglo XXI.

» Salud, I. N. (02 de septiembre de 2020). Instituto Nacional de Salud. Obtenido de https://www.ins.gov.co/Noticias/Paginas/coronavirus-pcr.aspx

» Semana. (14 de agosto de 2020). Carlos Camargo, elegido como nuevo defensor del Pueblo. Semana. Recuperado el 30 de agosto de 2020 de: https://n9.cl/oinf

» Sen, A. (2011). La idea de la justicia. Buenos Aires: Taurus.

» Supersalud. (2020). Informe de Gestión Supersalud Agosto2019-junio2020. Bogotá: Supersalud.

» Transparecia por Colombia. (03 de septiembre de 2020). Alarmante concentración del poder en el ejecutivo en Colombia. Obtenido de https://n9.cl/4m97

» Tribunal Administrativo de Cundinamarca, 2020-00185 (2020).

» Uprimny, R. (07 de septiembre de 2020). Dejusticia. Obtenido de https://www. dejusticia.org/column/un-duque-que-quiere-reinar/ 